\title{
Translesion DNA Polymerase eta functions in transcription elongation
}

\author{
Ph.D Thesis
}

\section{Vamsi Krishna Gali}

Supervisor: Dr. Ildikó Unk

Doctoral School of Biology of the Faculty of Science and Informatics University of Szeged

Institute of Genetics

Biological Research Centre of the Hungarian Academy of Sciences 


\section{Table of Contents}

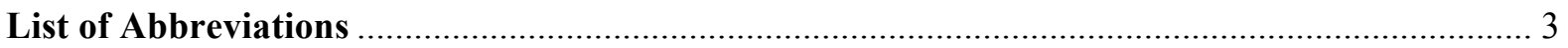

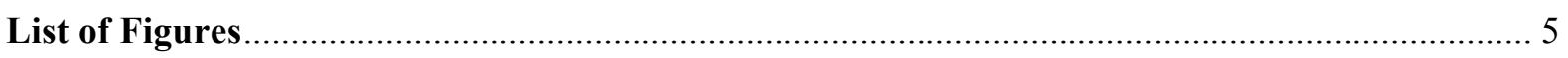

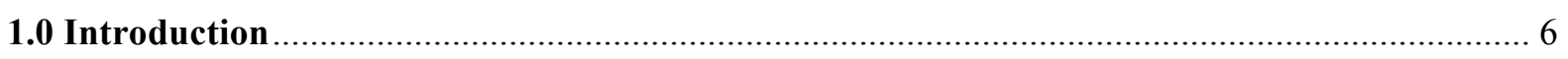

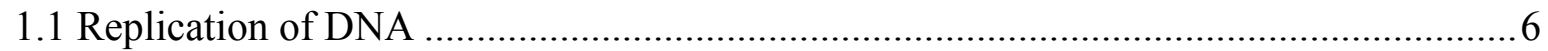

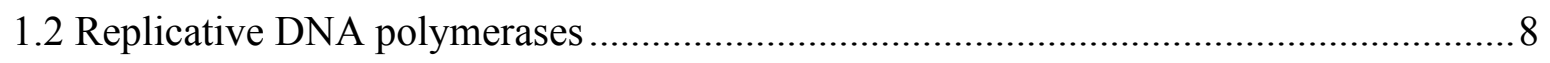

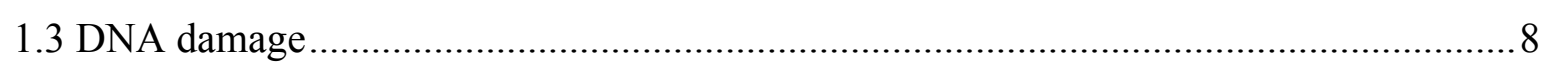

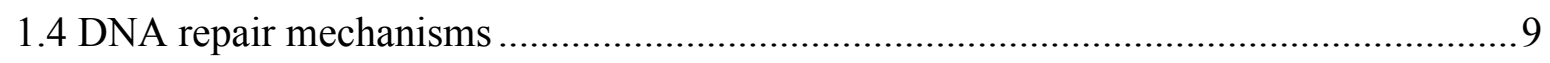

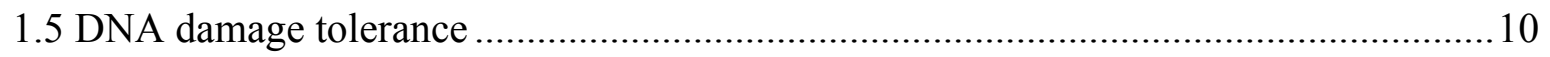

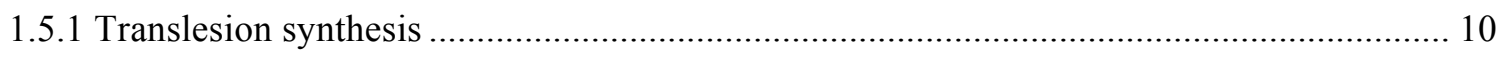

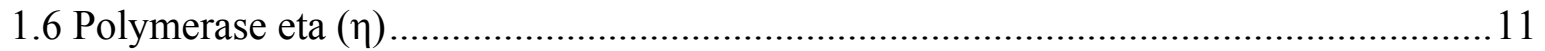

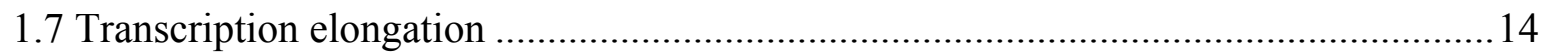

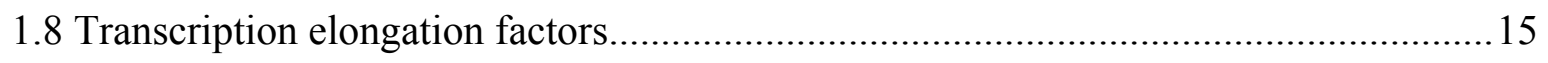

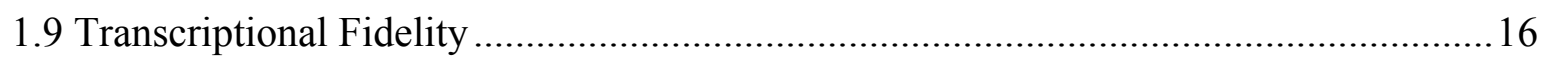

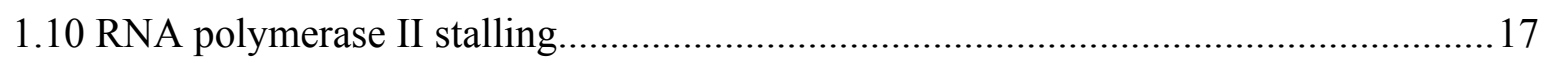

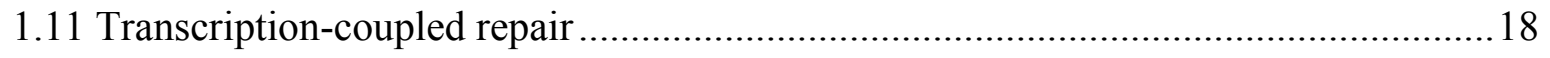

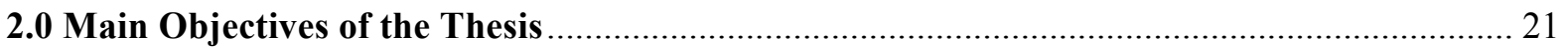

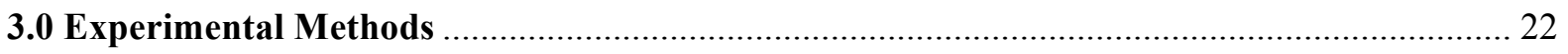

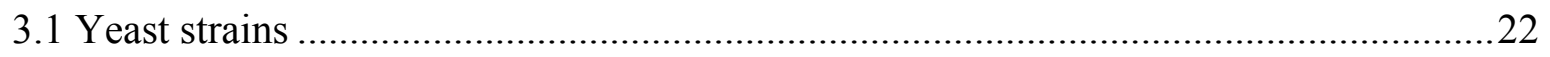

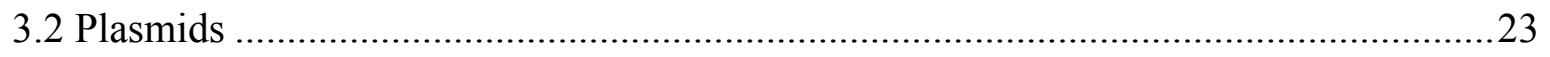

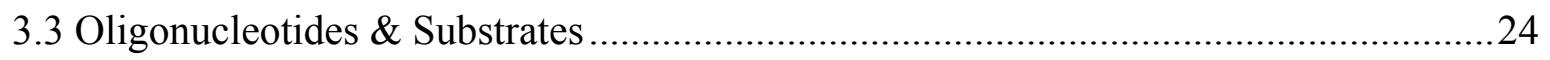

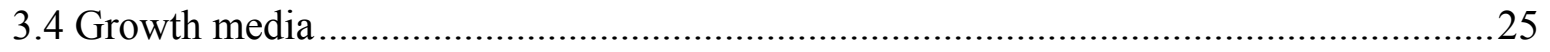

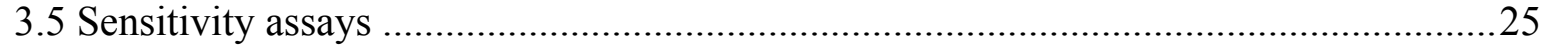

3.6 RNA analysis using reverse transcription quantitative real time PCR ........................26

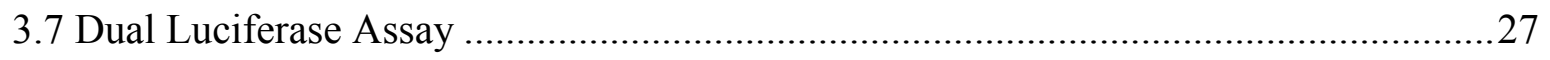

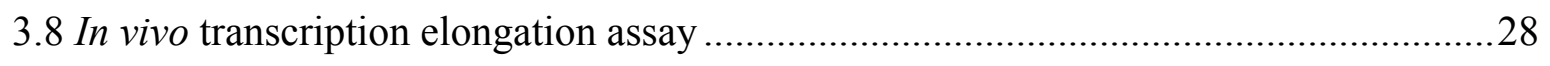

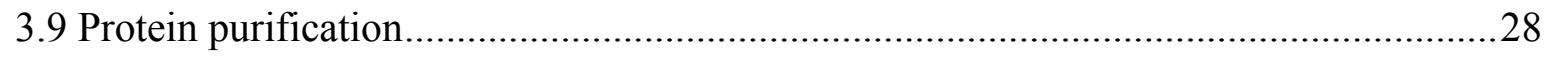

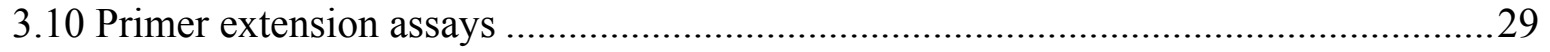

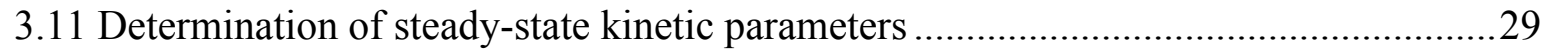

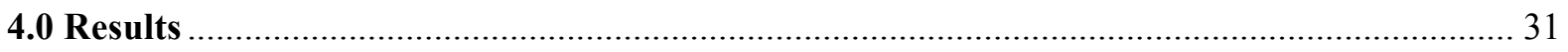

4.1 Polymerase eta confers resistance to transcription elongation inhibitors ......................31 
4.2 Induced synthesis of GAL10 mRNA is defective in Pol $\eta$ deficient strain 32

4.3 Expression of luciferase genes is defective in Pol $\eta$ deficient strain

4.4 Transcription elongation role of Pol $\eta$ as evidenced by in vivo transcription elongation

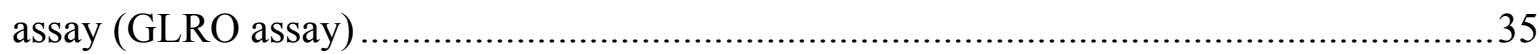

4.5 The catalytic activity of Pol $\eta$ is necessary for its role in transcription .........................37

4.6 Pol $\eta$ is capable of incorporating ribonucleotides in vitro opposite to undamaged and

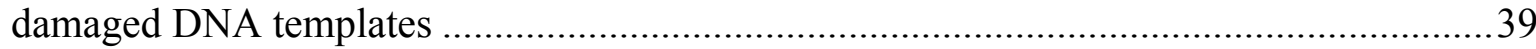

4.7 Analysis of ribonucleotide incorporation activity of Pol $\eta$ by steady state kinetics ......43

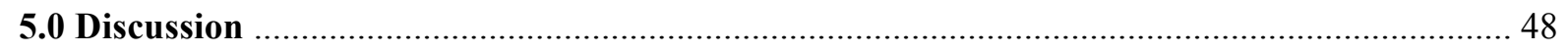

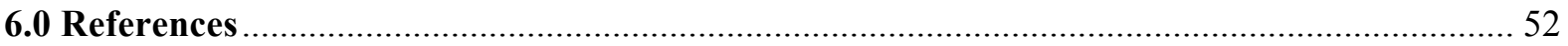

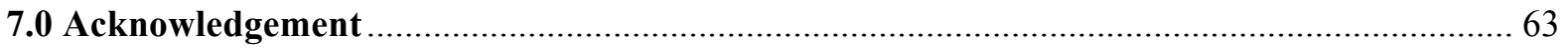

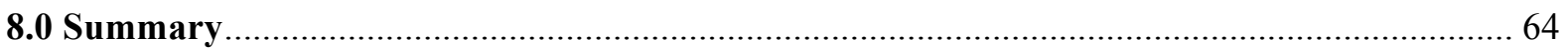

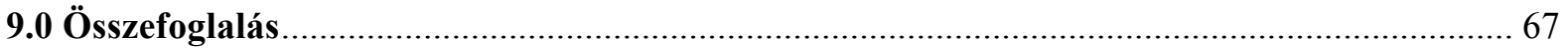




\section{List of Abbreviations}

\begin{tabular}{|l|l|}
\hline 8-oxoG & 8-oxoguanine \\
\hline BER & Base excision repair \\
\hline CPD & Cyclobutane pyrimidine dimers \\
\hline CTD & C-terminal domain \\
\hline DDT & DNA damage tolerance \\
\hline DNA & Deoxyribonucleic acid \\
\hline dNTP & Deoxyribonucleotide phosphate \\
\hline DSB & Double strand break \\
\hline FACT & Facilitator of chromatin transcription \\
\hline Fluc & Firefly luciferase \\
\hline FOA & 5-fluoro orotic acid \\
\hline GLRO & G-less Run on assay \\
\hline GST & Glutathione sepharose transferase \\
\hline HR & Homologous recombination \\
\hline ICL & Inter strand cross linkages \\
\hline m6G & 6-O-methyl guanine \\
\hline MMR & Mismatch repair \\
\hline MPA & Mycophenolic acid \\
\hline NER & Nucleotide excision repair \\
\hline NHEJ & Non-homologous end joining \\
\hline NTP & Nucleotide triphosphate \\
\hline ORF & Open reading frame \\
\hline PAD & Polymerase associated domain \\
\hline PAF & Polymerase II associated factor \\
\hline PCNA & Proliferating Cell Nuclear Antigen \\
\hline PCR & Polymerase chain reaction \\
\hline RFC & Replication Factor C \\
\hline Rluc & Renilla luciferase \\
\hline RNA & Ribonucleic acid \\
\hline RNAPII & RNA Polymerase II \\
\hline & Synthetic complete medium \\
\hline Single strand break \\
\hline
\end{tabular}




\begin{tabular}{|c|l|}
\hline SSBR & Single strand break repair \\
\hline TC-NER & Transcription coupled - Nucleotide excision repair \\
\hline TCR & Transcription coupled repair \\
\hline TFIIS & Transcription factor II S \\
\hline TLS & Translesion synthesis \\
\hline TT & Thymine-thymine dimer \\
\hline UV & Ultra violet light \\
\hline XPV & Xeroderma-pigmentosum variant \\
\hline
\end{tabular}




\section{List of Figures}

Figure 1. Model representing a typical eukaryotic replication fork .......................................

Figure 2. Illustration of DNA damage repair and bypass mechanisms ............................... 9

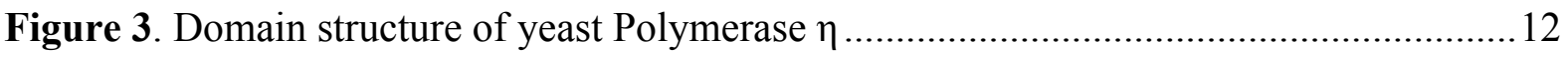

Figure 4. Transcription elongation by RNA polymerase II ................................................ 15

Figure 5. Schematic representations of possible ways that an RNAPII could allow NER

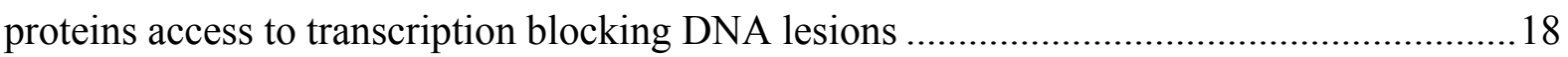

Figure 6. Outline of homology based recombination method for creation of deletion strains 22

Figure 7. Sensitivity of indicated strains to the transcription elongation inhibitor drug mycophenolic acid.

Figure 8. Induced synthesis of GAL10 mRNA as determined by real time RT-qPCR ..........33

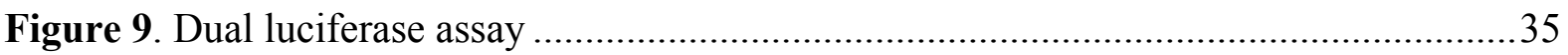

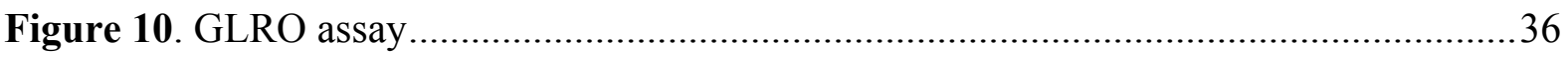

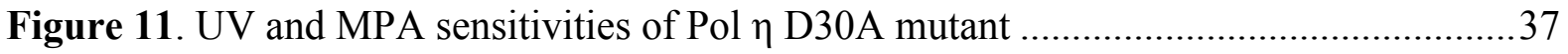

Figure 12. Induced level of GAL1 measured in Pol $\eta$ D30A mutant...................................38

Figure 13. Induced level of GAL10 measured in Pol $\eta$ D30A mutant ...................................39

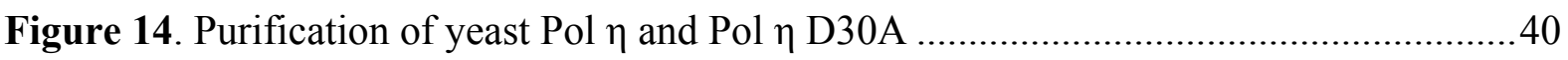

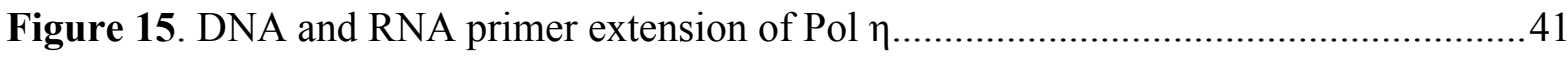

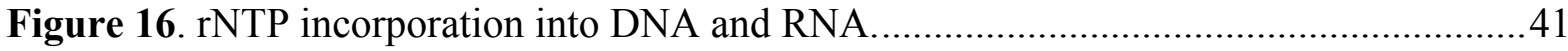

Figure 17. DNA and RNA extension by Pol $\eta$ opposite 8-oxoG.......................................43

Figure 18. Steady-state kinetic analysis of RNA primer extension with rNTPs...................45

Figure 19. Steady-state kinetic analysis of DNA primer extension with rNTPs ...................46

Figure 20. Graphical summary of transcription elongation and ribonucleotide incorporation

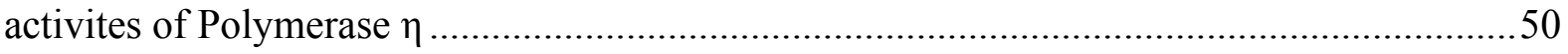




\subsection{Introduction}

\subsection{Replication of DNA}

Duplication of the genome in a timely and accurate manner is a crucial step for all living organisms. DNA replication is a process in which the entire genome of the organism is copied in a tightly controlled and coordinated fashion ensuring that the genome is duplicated properly and without errors. (Davey \& O'Donnell, 2000). Replication initiates at very specific locations distributed throughout the genome, known as origins of replication. The replication machinery or the replisome complex which carries out the synthesis is composed of many proteins which assemble at the origins and thereby support replication by DNA polymerases. The most important steps involved in the process of eukaryotic DNA replication are unwinding the DNA helix and synthesizing the new daughter strands of DNA. Replicative DNA helicases are responsible for unwinding the parental duplex DNA thereby exposing the two single-stranded DNA templates.

Once DNA helicases unwind the double helix, single stranded DNA binding protein known as Replication protein A (RPA) binds to stabilize the exposed single stranded template DNA. Replication of DNA is initiated by DNA polymerase alpha $(\alpha)$ which synthesizes a short RNA primer necessary for replication to begin. In yeast, a division of labor exists at the replication fork. Polymerase delta $(\delta)$ is known to carry out lagging strand synthesis, while, polymerase epsilon $(\varepsilon)$ performs the leading strand synthesis (Burgers, 2009; Kunkel \& Burgers, 2008; Nick McElhinny et al., 2008). However, DNA polymerases cannot act on their own. They need an accessory protein known as the proliferating cell nuclear antigen (PCNA) in eukaryotes, to carry out DNA synthesis. PCNA gets loaded onto the DNA by aided by the clamp loader which is known as Replication Factor C (RFC) (Burgers, 1991). While leading strand synthesis goes on unobstructed, lagging strand, owing to its orientation, is synthesized as short DNA 
fragments known as Okazaki fragments which are later sealed or ligated by DNA ligase to form a continuous strand. Once synthesized the chromatin structure comprising DNA and histone proteins is quickly re-established to enable the epigenetic inheritance as well as the tight packaging of genetic material. Altogether, a vast array of highly specialized proteins work in a tightly regulated fashion to accomplish the complex process of DNA replication which is also subject to a cell cycle control. A typical eukaryotic replication fork is depicted in Figure 1.

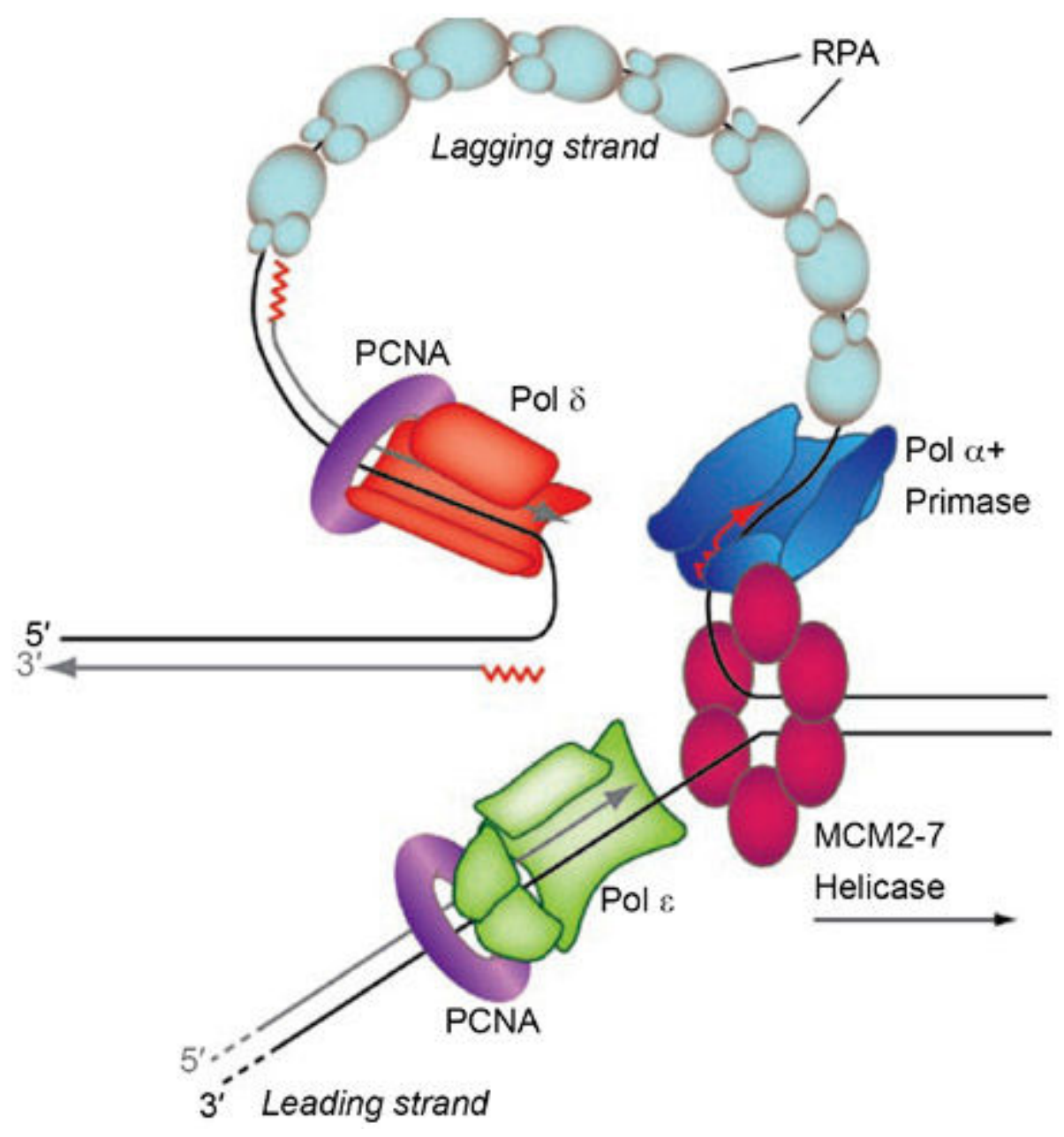

Figure 1. A model representing a typical eukaryotic replication fork (McCulloch \& Kunkel, 2008). 


\subsection{Replicative DNA polymerases}

Replicative DNA polymerases are responsible for carrying out the majority of DNA synthesis and in replicating the genome. Sequence homology and crystal structure analysis allows us to categorize DNA polymerases into seven different families: A, B, C, D, X, Y, and RT. In eukaryotes, the three DNA polymerases responsible for bulk genome replication belong to the B family and are Pol $\alpha, \operatorname{Pol} \delta$, and Pol $\varepsilon$. The three polymerases coordinate and act together along with other accessory proteins during DNA fork progression. Both Pol $\delta$ and Pol $\varepsilon$ contain a 3 ' to 5 ' proofreading exonuclease activity that enhances their fidelity by $10-60$-fold (McCulloch \& Kunkel, 2008). This exonuclease domain detects and removes any incorrect nucleotides allowing a correct one to be subsequently incorporated. Replicative DNA polymerases are known for their inherent high fidelity, even in the absence of the proofreading exonuclease domain. X-ray crystal structure of the classical polymerases, most recently, Pol $\delta$ have shown that the high fidelity is achieved by the active site pocket accommodating only the correct Watson-Crick base pair (Swan et al., 2009). In the event of a mismatch, polymerases stall through unfavorable interactions between the mismatch and the polymerase active site (Johnson \& Beese, 2004).

\subsection{DNA damage}

The process of DNA replication because of the sheer complexity is not always unobstructed. DNA is prone to damage because of metabolic activities which generate free oxygen radicals or due to exogenous sources such as ultraviolet light (UV) or chemical agents which result in modifications to DNA such as thymine dimers, double stranded breaks (DSBs) and other lesions. According to an estimate, in human cells about 10,000 abasic sites a day are generated, the consequences of which are mutations, stalled forks and genomic instability if repair processes are not initiated. (Lindahl, 1993; Lindahl \& Barnes, 2000). These lesions can cause blockage sites to replicative DNA polymerases because of their high fidelity for insertion of 
correct nucleotides. Prolonged stalling of replication fork can lead to serious consequences such as cell death.

\subsection{DNA repair mechanisms}

To efficiently duplicate the genome and minimise the effects of DNA lesions, cells have evolved multiple ways known as DNA damage responses (Figure 2).

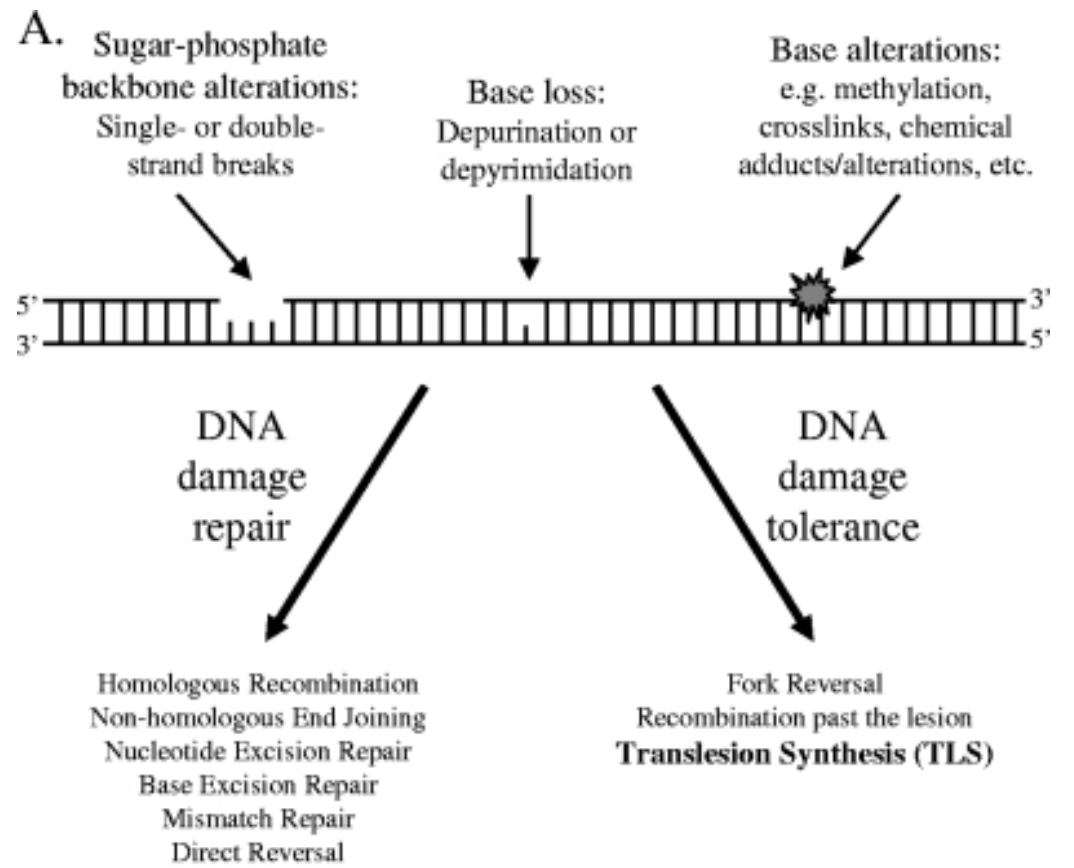

B.

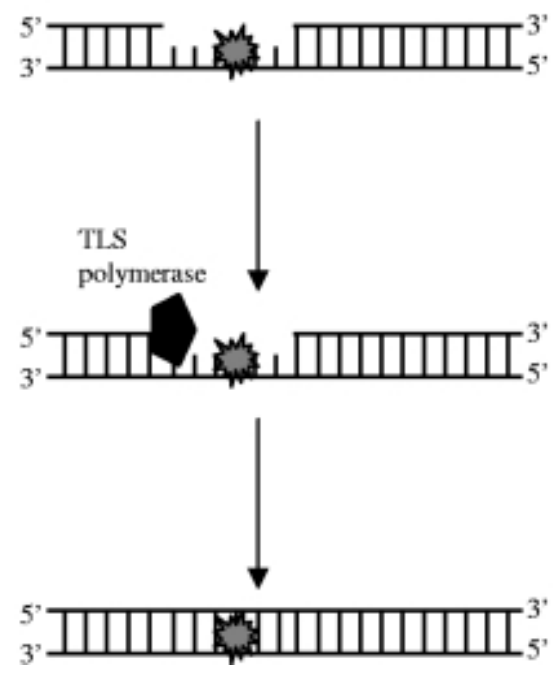

Figure 2.Illustration of DNA damage repair and bypass mechanisms A. Different ways of damage and repair mechanisms B. DNA damage tolerance carried out by TLS polymerase (Waters et al., 2009). 
Mismatched DNA bases get replaced with correct bases by mismatch repair (MMR), and other mismatches are repaired by another process known as base excision repair (BER) through simple excision of the damaged base (Jiricny, 2006; Lindahl \& Barnes, 2000). Other complex lesions such as CPDs and intra-strand crosslinks are repaired by nucleotide excision repair (NER). During this process, an oligomer of approximately 25 base pairs gets excised, while Inter-strand cross linkages (ICLs) are excised by ICL repair (Hoeijmakers, 2009; Moldovan \& D'Andrea, 2009). Single stranded breaks (SSBs) are repaired by single-strand break repair (SSBR), whereas double stranded breaks (DSBs) are processed either by non-homologous end joining (NHEJ) or homologous recombination (HR) (Caldecott, 2008).

\subsection{DNA damage tolerance}

When DNA repair cannot happen immediately, polymerase stalling may result in genomic instability. To avoid this, cells have evolved DNA damage tolerance mechanisms, or postreplication repair processes, which allow them to replicate over polymerase-blocking lesions (Friedberg, 2005). Translesion synthesis (TLS) and template switching are the two different ways in which cells can tolerate DNA damage. During translesion synthesis, specialized DNA polymerases replicate directly past the lesion in either an error-prone or error-free fashion. While TLS is error-prone, processes such as template switching are essentially error-free as the mechanism involves using an alternative, undamaged template DNA to carry out the repair process.

\subsubsection{Translesion synthesis}

The predominant mechanism of DNA damage tolerance is translesion synthesis. In contrast to replicative DNA polymerases, which synthesize DNA with a high degree of accuracy and are blocked by lesions that significantly distort the geometry of DNA, TLS DNA polymerases, particularly of the $\mathrm{Y}$ family, synthesize DNA with much higher error rates and are able to 
synthesize DNA past lesions that block replicative polymerases. The eukaryotic non-classical polymerases involved in translesion synthesis are polymerase $\zeta$, polymerase $\eta$, polymerase 1 , polymerase $\kappa$, and the Rev1 protein (Prakash et al. 2005). These polymerases are all members of the Y family, except Pol $\zeta$ which is a B family member. Pol $\eta$ is able to bypass different types of lesions, predominantly UV photoproducts (Washington et al, 2000). Pol 1 and Rev1 both function as inserters, incorporating directly across from a DNA lesion, such as abasic sites and 8-oxo-guanine (8-oxoG) (Haracska et al, 2001b; Nair et al, 2005; Washington et al, 2004). Pol $\kappa$ is believed to be involved in bypassing adducts on the N2 position of guanine, such as benzo[a]pyrene guanine (Avkin et al, 2004; Ogi et al, 2002; Takenaka et al, 2006). Furthermore, Pol $\kappa$ and Pol $\zeta$ are efficient extenders from DNA lesions (Haracska et al, 2002; Haracska et al, 2003; Washington et al, 2000; Washington et al, 2004). Proliferating cell nuclear antigen (PCNA) provides the central scaffold to which the various TLS polymerases bind to gain access to the replicative ensemble stalled at the lesion site and to execute their roles in lesion bypass. Recent evidence shows that TLS polymerases gain access to the stalled replication site through a DEF1 dependent mechanism (Daraba et al, 2014). Def1 was previously identified as an RNA Polymerase II (RNAPII) degradation factor (Woudstra et al, 2002a). Monoubiquitylated PCNA activates TLS, for which to occur, the catalytic sub unit of Pol $\delta$ is ubiquitylated by a Def1-dependent manner and removed from the stalled Pol $\delta$ complex through proteasomal degradation. Then, TLS polymerase teams up with the remaining Pol $\delta$ subunits, at the stalled fork to form a new complex capable of performing DNA lesion bypass.

\subsection{Polymerase eta $(\eta)$}

Pol $\eta$ is a very well characterized TLS polymerase. In humans, loss of Pol $\eta$ activity results in a cancer-prone syndrome known as xeroderma pigmentosum variant (XPV). It is characterized by an increased incidence of skin cancers and sensitivity to sunlight (Kawamoto et al, 2005b; Lehmann, 2005; Masutani et al, 1999). Clinically, XPV is very similar to other forms of 
xeroderma pigmentosum, which result from mutations in any of six key nucleotide excision repair genes, but XPV cells are not defective in nucleotide excision repair (Lichon \& Khachemoune, 2007). This phenotype highlights the predominantly non-mutagenic role of Pol $\eta$, setting it apart from the more mutagenic functions of Pol $\zeta$ and Rev1.

Polymerase domain

\begin{tabular}{|l|l|l|l|l|l|}
\hline & PAD & & UBZ & NLS & PIP \\
\hline
\end{tabular}

Figure 3.Domain structure of yeast Polymerase $\eta$.

The polymerase domain of the protein present at its N-terminus is responsible for the catalytic activity of Pol $\eta$ (Figure 3) and also shares sequence homology with other Y-family polymerases (Ohmori et al, 2001). Pol $\eta$ also includes a Polymerase Associated Domain (PAD), also known as the Little Finger, which participates both in DNA binding and in several specific protein-protein interactions (Jung et al, 2010; Trincao et al, 2001). Pol $\eta$ is recruited to the DNA by a C-terminal region of 100 to 200 amino acids, which includes a nuclear localization sequence (NLS), a PCNA-interacting region (PIP), and a ubiquitin-binding zinc finger domain (UBZ) (Bienko et al, 2005; Bienko et al, 2010; Kannouche et al, 2001; Plosky et al, 2006).

Pol $\eta$ encoded by $R A D 30$ gene in S.cerevisiae is part of the RAD6 epistasis group (McDonald et al, 1997) but appears to function independently of both the error-free pathway defined by $R A D 5$ and the error-prone TLS pathway which includes REV1, REV3, and REV7 (McDonald et al, 1997). The regulation of the catalytic activity of Pol $\eta$ is directed mostly through the various protein interactions. Pol $\eta$ interacts with the eukaryotic processivity clamp, PCNA, through its C-terminal PCNA-binding motif (PIP box) (Kannouche et al, 2004), and 
the interaction between PCNA and Pol $\eta$ plays an important role in Pol $\eta$ function. This may be partially attributable to the stimulatory effect of PCNA on Pol $\eta$ 's TLS activity in vitro (Haracska et al, 2001a; Kannouche et al, 2001). Although ubiquitinated PCNA is not required for Pol $\eta$ to access stalled replication forks in vitro (Nikolaishvili-Feinberg et al, 2008), Pol $\eta$ 's interaction with PCNA can be enhanced by the monoubiquitination of PCNA.

Pol $\eta$ was first identified in yeast and deletion of $R A D 30$ in yeast conferred an enhancement of UV mutagenesis. The ability of Pol $\eta$ and other Y-family polymerases to replicate through DNA lesions implies that they are not inhibited by the geometric distortions imposed by the presence of lesions in DNA. In its proficient ability to replicate through cyclobutanepyrimidine dimers (CPDs), Pol $\eta$ is the most efficient of all other known DNA polymerases. This proficiency of $\mathrm{Pol} \eta$ derives from its unique structural feature, the ability to accommodate both template nucleotides of a CPD in its active site (Trincao et al, 2001). Both yeast and human Pol $\eta$ replicate through a cis-syn TT dimer by inserting two As opposite the two Ts of the dimer. Steady-state kinetic analyses have shown that the incorporation of an A opposite the 3'T and the $5^{\prime} \mathrm{T}$ of the dimer occurs with nearly the same efficiency and fidelity as opposite the two undamaged Ts (Johnson et al, 2000). Pol $\eta$ can also by-pass a (6-4) TT lesion. Although Pol $\eta$ is unable to replicate past the (6-4) TT lesion, it can preferentially incorporate a G opposite the 3' $T$ of the lesion. Pol $\zeta$ performs the subsequent extension step.

Pol $\eta$ plays a prominent role in efficient and accurate replication through the 8-oxoG lesion. The efficiency with which yeast Pol $\eta$ incorporates a $\mathrm{C}$ opposite the lesion and then extends from the inserted nucleotide is remarkably similar to that at an undamaged G (Haracska et al, 2000b). Pol $\eta$ can replicate through a 6-o-methyl guanine (m6G) lesion, but opposite this lesion, it incorporates the $\mathrm{C}$ and $\mathrm{T}$ nucleotides nearly equally well. In contrast to the efficient bypass of CPDs and 8-oxoG lesions, replication through the m6G lesion is inhibited $\sim 20$-fold at the nucleotide incorporation step (Haracska et al, 2000a). 


\subsection{Transcription elongation}

Damage to DNA affects not only the process of replication, but also transcription where DNA is used as a template to produce nascent mRNA.

Transcription is the very first step of gene expression, in which a particular segment of DNA, structured as a gene is copied into RNA by the enzyme RNA polymerase. Transcription of protein-coding genes by RNAPII is a dynamic process that begins with the formation of a preinitiation complex (PIC) at the promoter and proceeds through initiation, elongation, termination, and, finally, re-initiation (Hahn, 2004). Interaction of a number of transcription factors with RNAPII and chromatin is important for regulating the process of transcription. An RNAPII complex capable of initiating mRNA sythesis is formed by interacting between promoter specific activators, chromaatin remodeling enzymes, and general transcription factors. (Kuras \& Struhl, 1999).

After dissociating from most of the transcription factors for initiation and promoter clearance, the polymerase recruits additional factors for the next phase of transcription, which is elongation (Pokholok et al, 2002a; Wade \& Struhl, 2008). Incoming DNA is unwound by helicases before the polymerase active site and is rewound beyond it to form the transcription bubble. In the unwound region, the DNA template strand forms a hybrid duplex with growing mRNA. RNAPII selects NTPs in a template-directed manner. First, the incoming nucleotide binds to an entry site beneath the active centre in an inverted orientation. Second, the NTP rotates into the nucleotide addition site for sampling of correct pairing with the template DNA. Only correctly paired NTPs can transiently bind the insertion site. Third, is the pretranslocation step in which phosphodiester bond formation occurs. Fourth, translocation occurs to repeat the cycle. At the upstream end of the hybrid, RNA pol II separates the nascent RNA from the DNA. (Figure 4). 


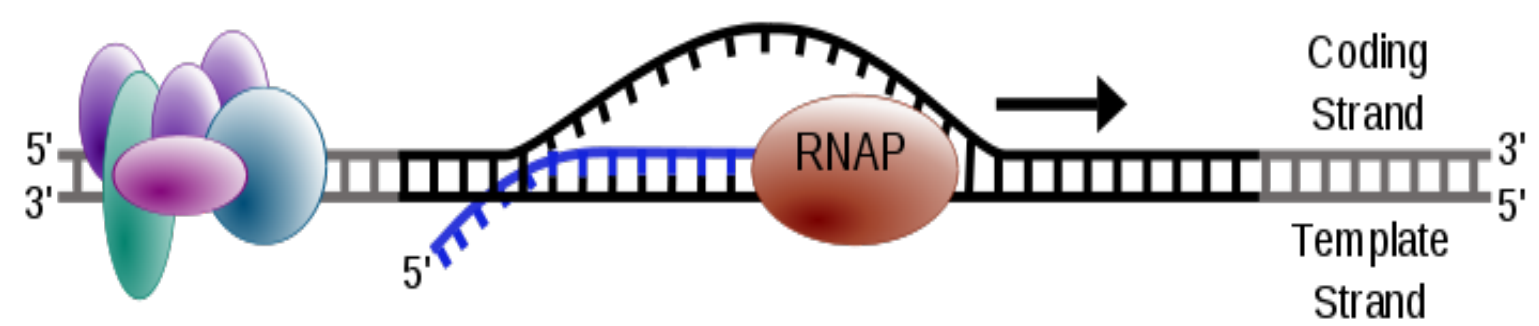

Figure 4.Transcription elongation by RNA polymerase II.

\subsection{Transcription elongation factors}

The efficiency of elongation by RNAPII is regulated by a number of factors such as TFIIS, Facilitates Chromatin Transcription (FACT), Spt6, Rtt106 and RNA polymerase-associated factor 1(Paf) (Sims et al, 2004). TFIIS in yeast encoded by the DST1 gene. It is a typical transcription elongation factor and is highly conserved among eukaryotes with homologs such as GreA in eubacteria. (Fish \& Kane, 2002; Labhart \& Morgan, 1998). TFIIS promotes the reactivation of the RNAPII when it is stalled. TFIIS induces endonucleolytic cleavage, typically releasing dinucleotides if the polymerase is stalled and four or more nucleotides if arrested (Gu et al, 1993; Izban \& Luse, 1993). Arrested RNA polymerases are formed after backtracking and extrusion of the $3^{\prime}$-end of the RNA from the catalytic centre (Kireeva et al, 2000; Komissarova \& Kashlev, 1997). The stimulation can reactivate RNAPII by TFIIS of the intrinsic RNA cleavage activity of the polymerase (Kettenberger et al, 2003; Rudd et al, 1994). A failed RNA polymerase because of stalling results in aberrant transcripts, reduced mRNA and eventually genomic instability (Reines et al, 1999).

FACT was discovered during a study which involved experiments designed to identify factors support RNAPII transcription. (Orphanides et al, 1998). With a high degree of conservation among eukaryotes, FACT complex plays a role after the initiation step of transcription and is totally independent of factors such as TFIIF and TFIIS. (Belotserkovskaya et al, 2004). FACT complex in yeast is comprised of two essential subunits, Spt16 and Pob3. Genetic studies in yeast had identified the later recognized subunits of FACT as having a role in productive 
elongation through chromatin. The FACT components of yeast are implicated in the regulation of transcription and chromatin structure by disrupting nucleosome dimers and tetramers, as well as the timely and proper progression though the cell cycle (Malone et al, 1991; Rowley et al, 1991).

PAF was initially identified as a RNAPII associated factor that can interact with elongation factors, Spt4, FACT and Transcription Binding Protein (TBP). It is found in a complex with four additional subunits, Ctr9, Cdc73, Rtf1 and Leo1 (Krogan et al, 2002; Mueller \& Jaehning, 2002; Shi et al, 1997; Shi et al, 1996). Genetic studies of Paf subunits revealed a wide range of phenotypes, including transcript elongation phenotypes (Costa \& Arndt, 2000). The interaction of PAF complex with the elongation factors is a critical step during transcription elongation and defects in PAF complex may lead to elongation defects. The PAF complex has also been demonstrated to cross-link throughout the entire length of genes, consistent with its functioning as an elongation factor (Pokholok et al, 2002b).

Snf5 is also involved in transcription elongation. It is a member of the SWI/SNF complex (Cairns et al, 1994; Peterson et al, 1994; Smith et al, 2003) that affects chromatin structure and transcription from a variety of promoters (Abrams et al, 1986; Happel et al, 1991; Hirschhorn et al, 1992; Laurent et al, 1990; Laurent et al, 1991). Snf5 null mutants are viable but display reduced growth. However, in combination with another transcription elongation factor, Dst1, null mutation is lethal. By regulating the structure of chromatin, chromatin remodeling complexes, all of which contain an ATPase as a central motor subunit, perform critical functions in the maintenance, transmission, and expression of eukaryotic genomes.

\subsection{Transcriptional Fidelity}

Insertion of correct nucleotides into the newly synthesized RNA transcript during transcription elongation is essential for accurate gene expression. RNAPII must balance the need for rapid 
transcription with the need for high fidelity so that only the nucleoside triphosphate substrate specified by the DNA template is selected. An important structural feature of RNAPII called the trigger loop, a mobile element of the Rpb1 subunit, is its key feature in maintaining RNAPII fidelity during transcription (Brueckner \& Cramer, 2008b; Kaplan et al, 2008).

During transcription elongation, the incoming ribonucleotide interacts with the trigger loop which is located under the active site (Wang et al, 2006). These interactions ensure that the trigger loop and the incoming nucleotide are correctly aligned, which is required for nucleophilic attack and phosphodiester bond formation. Both nucleotide selection and phosphodiester bond formation may be mediated by the trigger loop and are likely to be coupled. Mismatched nucleotides in the active site are not aligned properly with the trigger loop and therefore result in a substantial reduction in the rate of phosphodiester bond formation (Brueckner \& Cramer, 2008b; Kaplan et al, 2008; Kornberg, 2007).

\subsection{RNA polymerase II stalling}

RNAPII will efficiently transcribe DNA only if it can overcome obstacles on the template strand. Otherwise, RNAPII may stall, and it could result in aberrant transcriptional products. Cells face many such obstacles, including DNA-binding proteins, unusual DNA structures, and nucleosomes. However, the most prominent obstacle to the progression of the polymerase is likely to be DNA lesions (Svejstrup, 2002). Several types of DNA lesions are known to block transcription by RNAPII in vitro as well as in vivo, and, since transcription proceeds

unidirectionally, an irreversibly trapped polymerase is not an option for the cell if it has to avoid genomic instability. Cells have therefore efficient systems in place to respond to and thereby rescue any stalled transcription complexes and contribute to cell viability (Conaway et al, 2000). 


\subsection{Transcription-coupled repair}

Transcription-coupled repair (TCR) occurs when an elongating RNAPII encounters an obstacle and cannot continue synthesizing transcripts. Arrested transcription complexes may severely affect cellular functions and survival, inhibiting the production of essential transcripts, blocking DNA replication and signaling pathways that might even trigger cell death. Moreover, a RNAPII able to bypass a lesion can generate mutant, perhaps deleterious transcripts which is why a proper repair becomes essential.

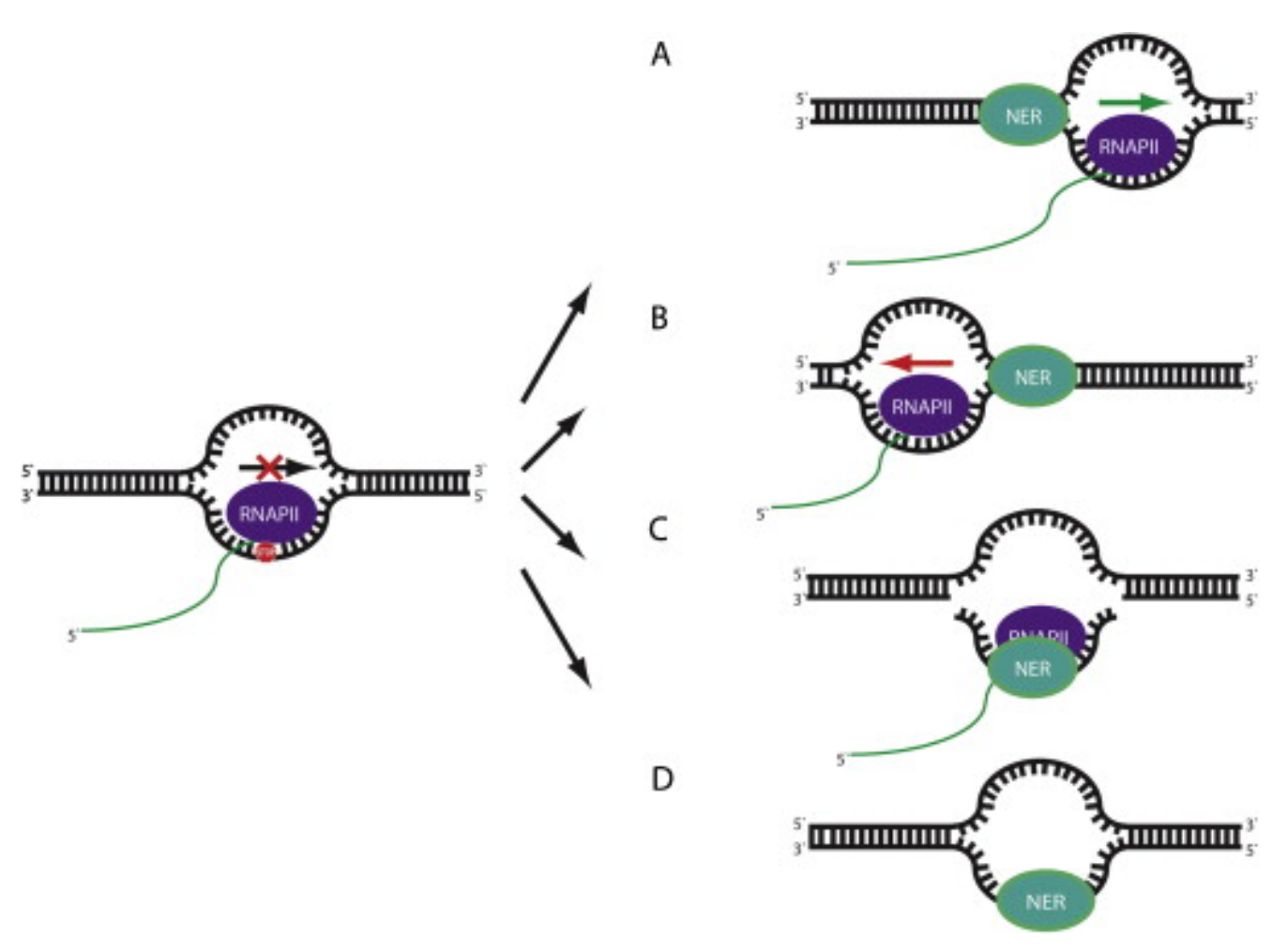

Figure 5. Schematic representations of possible ways that a RNAPII could allow NER proteins access to transcription-blocking DNA lesions (Adapted from McKay \& Cabrita, 2013). A. RNAPII may be able to bypass the DNA lesion. NER B. RNAPII may then repair the bypassed lesion may reverse translocate to allow the assembly of the NER complex. C. RNAPII remains stably associated with the DNA lesion as a ternary complex with the nascent mRNA and the damaged DNA strand. D. RNAPII may be degraded in a proteasome-dependent manner to expose the DNA lesion for assembly of the NER complex and repair of the lesion. 
Transcription and the co-transcriptional production of functional mRNA are complicated by the presence of endogenous and exogenous sources of DNA damage. In vitro, RNAPII blocked at a CPD forms a stable ternary complex covering between 35 and 40 nucleotides centred symmetrically over the lesion (Tornaletti et al, 1999). An RNAPII tightly associated with DNA might prevent repair synthesis. In order to bypass this problem, it is widely believed that the polymerase must be displaced in order to repair the blocking DNA lesions, which also allows recruitment of repair proteins. There are a variety of hypotheses that have been proposed for the blocked polymerase to deal with transcription-blocking lesions (Figure 5).

The RNAPII complex could be blocked initially, but it may be capable of bypassing lesions without an immediate requirement for repair. Although it has been reported that a single CPD is an absolute block to RNAPII in vitro (Tornaletti et al, 1997; Tornaletti et al, 1999) there is clear evidence that RNAPII can bypass CPD and another bulky DNA adduct, 8,5'-cyclo-2'deoxyadenosine (cyclo-dA) in vivo (Marietta \& Brooks, 2007). Recent evidence in yeast suggests that transcription-coupled translesion mRNA synthesis may rescue a stalled RNA polymerase following UV-irradiation (Walmacq et al, 2012). However, the synthesis past CPD in vitro was quite inefficient.

Reverse translocation may also displace a stalled RNA polymerase (Gnatt, 2002; Wind \& Reines, 2000). In vitro experiments with purified RNAPII and templates with a site specific CPD indicated that TFIIS is capable of displacing the RNAPII by the retrograde movement to allow a bacteriophage DNA repair enzyme to access the lesion, permitting the eventual bypass of the damage site by the arrested RNAPII (Tornaletti et al, 1999).

Repair may also occur without having to displace the RNAPII from stalled transcription sites. This can be achieved by forming a stable ternary complex that promotes the recruitment and assembly of a functional repair complex (Mellon et al, 1987; Selby \& Sancar, 1997). In vitro footprinting of RNAPII arrested at a CPD indicates that the polymerase protects a region 
of 35-40 nucleotides located around the lesion (Selby \& Sancar, 1997; Tornaletti et al, 1997). Noticeably, the arrested polymerase did not block access of the NER complex to the CPD suggesting that the damaged DNA strand could be excised without the polymerase being displaced (Sarker et al, 2005; Selby \& Sancar, 1997). However, following incision, a ternary complex consisting of the polymerase, the nascent mRNA and the damaged oligonucleotide must occur. During transcription coupled nucleotide excision repair (TC-NER), the damaged oligonucleotide will be dissociated from the complementary strand of DNA to allow DNA synthesis across the repair site (Bowman et al, 1997b). Restart of nascent RNA synthesis by the stalled RNAPII would then require the release of the damaged oligonucleotide from the active site followed by a productive association with the newly synthesized and repaired template strand of DNA without disrupting the ternary complex.

Yet another hypothesis put forward to resolve a blocked RNA polymerase is its release from the template altogether. RPB1, which is the largest sub-unit of RNAPII was shown to be ubiquitinated in a Cockayne syndrome $\mathrm{A}$ and $\mathrm{B}$ proteins (CSA\&CSB) dependent manner following exposure to UV light and the chemotherapeutic agent such as cisplatin (Bregman et al, 1996; Ratner et al, 1998). This led to the hypothesis that RPB1 could be ubiquitinated at the site of DNA damage and subsequently degraded through a proteasome-mediated mechanism allowing access of the DNA repair complex to sites of transcription blocking DNA. It was shown that RNAPII stalled at a DNA lesion elicits a rescue response that requires the Rad26Defl complex, following which Defl enables ubiquitination and proteolytic degradation of Rpb1 when the lesion cannot be rapidly removed by Rad26-promoted DNA repair (Woudstra et al, 2002b). 


\subsection{Main Objectives of the Thesis}

We discovered that deletion of Polymerase $\eta$ in yeast leads to a transcription elongation inhibitor sensitive phenotype. This result and other preliminary results led us to formulate a hypothesis that Pol $\eta$ functions in the process of transcription.

To verify this hypothesis, we sought to answer the following questions:

a. Does Pol $\eta$ function in the process of transcription?

b. Which step in transcription does Pol $\eta$ play a role?

c. What role does the active centre of Pol $\eta$ have in this process?

d. Does Pol $\eta$ have the ability to incorporate ribonucleotides opposite to undamaged and damaged DNA templates? 


\subsection{Experimental Methods}

\subsection{Yeast strains}

All yeast strains used in this study are BY4741 (MATa, his3-D1, leu2 D0, met15D0, ura3D0) and its derivatives which were obtained from the Euroscarf collection. Gene deletions were made by replacing most of the open reading frame $(\mathrm{ORF})$ with a marker gene by a homologous recombination based method (Figure 6). Homologous regions, approximately 200 base pairs specific for a particular gene on each side of the coding sequence were initially cloned into a cloning vector. Then, a marker gene (eg. URA3, HIS3, TRPI) was cloned between the two homologous arms. For deletion of a gene, the homologous regions and the marker containing cassette was digested with restriction enzymes from the cloning vector and transformed into the respective yeast strain by high efficiency yeast transformation method (Gietz \& Schiestl, 2007).

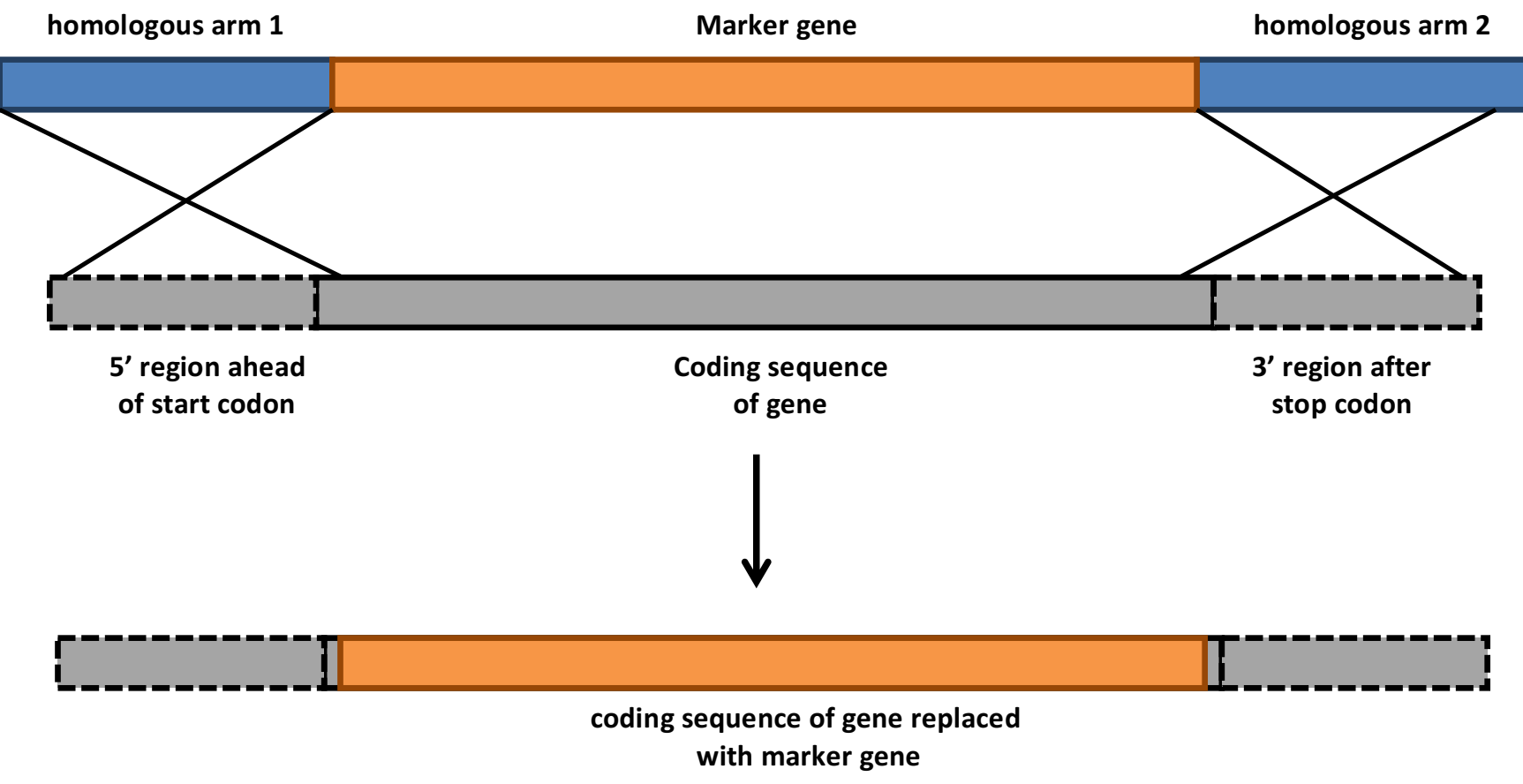

Figure 6.Graphical outline of homology based recombination method for creation of deletion strains. 
Transformants were selected on marker specific omission media. Deletions were later confirmed by PCR. Site specific integration of point mutations at the genomic locus was carried out as described (Gray et al, 2004). Initially, the coding sequence of a specific gene was replaced with an URA3 selection marker by using homology based recombination method. Following that, a linear fragment of coding sequence containing the desired mutation made by site directed mutagenesis and corresponding to the deleted sequence was transformed into yeast alongside an empty vector containing a selection marker. The empty vector allows for growth of manageable number of colonies among which recombination of the mutant coding sequence could have taken place at the genomic locus, replacing the URA3 selection marker previously integrated with the mutant coding sequence. The colonies are then replica plated on 5-fluoro orotic acid (FOA) selection plates to identify the ones which lost the URA3 marker, and with mutant coding sequence integrated in its place. Genomic changes were confirmed by PCR and sequencing. BJ5464 yeast strain (MAT $\alpha$, ura3-52 trp1 leu2-1 his3-200 pep4::HIS3 prb1-D1.6R can1 GAL) was used for protein overexpression.

\subsection{Plasmids}

The dual luciferase assay plasmid was constructed as follows. A dual promoter containing vector, pY25GAL1-GPD, containing bidirectional GPD and GAL1 promoters was purchased from Turbo biotech, China. First, the renilla luciferase gene was amplified by PCR using a template plasmid as a blunt-ended fragment. The PCR fragment was cloned into SmaI site under the constitutively expressing promoter GPD. Then, firefly luciferase gene was amplified by PCR using a template plasmid and the PCR fragment was cloned as a blunt- ended fragment into NotI site under the inducible promoter GAL1. The luciferase genes with their respective promoters and terminators were further cloned into the centromeric plasmid YCplac33 to generate the plasmid, pID 723 used for Dual luciferase assay. For protein purification, wild type and D30A mutant Pol $\eta$ were overexpressed in N-terminal fusion with glutathione $S$ - 
transferase (GST) gene by cloning into a pBJ842 backbone to generate the plasmids pID 206 and pID 797 respectively (Johnson et al, 2006). pCYC-LacZ (GLRO-long) plasmid used for GLRO assays was a kind gift from Andres Aguillera (Tous et al, 2011).

\subsection{Oligonucleotides \& Substrates}

Oligonucleotides used in this study were purchased from Integrated DNA Technologies, except for the 8-oxoG containing oligo, which was purchased from Midland Certified Reagent Co. For substrates used in primer extension assays, fluorescent labeled primers were annealed to the respective DNA templates by incubation at 100C for 5 minutes (DNA: DNA hybrids) or $80^{\circ} \mathrm{C}$ for 5 minutes (RNA: DNA hybrids) and then gradually cooling down to room temperature.

\begin{tabular}{|c|c|}
\hline S1 & $\begin{array}{l}\text { /5CY3/CGCTACCTAGCCTGCCTCAAGAGTTGCTCG } \\
\text { 3'-GCGATGGATCGGACGGAGTTCTCAACGAGCACAGGCTTACGCTCAGGTCG-5', }\end{array}$ \\
\hline S2 & $\begin{array}{l}\text { /5CY3/CGCTACCTAGCCTGCCTCAAGAGTTGCTCG } \\
\text { 3'-GCGATGGATCGGACGGAGTTCTCAACGAGCTCAGGCTTACGCTCAGGTCG-5', }\end{array}$ \\
\hline S3 & $\begin{array}{l}\text { /5CY3/CGCTACCTAGCCTGCCTCAAGAGTTGCTCG } \\
\text { 3'-GCGATGGATCGGACGGAGTTCTCAACGAGCGCAGGCTTACGCTCAGGTCG-5' }\end{array}$ \\
\hline S4 & $\begin{array}{l}\text { /5CY3/CGCTACCTAGCCTGCCTCAAGAGTTGCTCG } \\
\text { 3'-GCGATGGATCGGACGGAGTTCTCAACGAGCCCAGGCTTACGCTCAGGTCG-5' }\end{array}$ \\
\hline S5 & $\begin{array}{l}\text { /5CY3/CGCUACCUAGCCUGCCUCAAGAGUUGCUCG } \\
\text { 3'-GCGATGGATCGGACGGAGTTCTCAACGAGCACAGGCTTACGCTCAGGTCG-5' }\end{array}$ \\
\hline S6 & $\begin{array}{l}\text { /5CY3/CGCUACCUAGCCUGCCUCAAGAGUUGCUCG } \\
\text { 3'-GCGATGGATCGGACGGAGTTCTCAACGAGCTCAGGCTTACGCTCAGGTCG-5' }\end{array}$ \\
\hline S7 & $\begin{array}{l}\text { /5CY3/CGCUACCUAGCCUGCCUCAAGAGUUGCUCG } \\
\text { 3'-GCGATGGATCGGACGGAGTTCTCAACGAGCGCAGGCTTACGCTCAGGTCG-5', }\end{array}$ \\
\hline S8 & $\begin{array}{l}\text { /5CY3/CGCUACCUAGCCUGCCUCAAGAGUUGCUCG } \\
\text { 3'-GCGATGGATCGGACGGAGTTCTCAACGAGCCCAGGCTTACGCTCAGGTCG-5' }\end{array}$ \\
\hline S9 & $\begin{array}{l}\text { /5cy3/CGACGATGCTCCGGTACTCCAGTGTAGGCAT } \\
\text { 3'-CAAAAGGGTCAGTGCTGCTACGAGGCCATGAGGTCACATCCGTAGAATGCTTAAGAACTCC } \\
\text { GTCCGTACCATCGA-5' }\end{array}$ \\
\hline
\end{tabular}




\begin{tabular}{|c|c|}
\hline S10 & $\begin{array}{l}\text { /5cy3/CGACGATGCTCCGGTACTCCAGTGTAGGCAT } \\
\text { 3'-CAAAAGGGTCAGTGCTGCTACGAGGCCATGAGGTCACATCCGTA }{ }^{\mathbf{0}} \text { GAATGCTTAAGAACTCC } \\
\text { GTCCGTACCATCGA-5' }\end{array}$ \\
\hline S11 & $\begin{array}{l}\text { /5cy3/CGACGATGCTCCGGTACTCCAGTGTAGGCAT } \\
\text { 3'-CAAAAGGGTCAGTGCTGCTACGAGGCCATGAGGTCACATCCGTAGAATGCTTAA } \\
\text { GAACTCCGTCCGTACCATCGA-5' }\end{array}$ \\
\hline S12 & \begin{tabular}{l}
\multicolumn{1}{l}{$/ 5 \mathrm{cy} 3 /$ CGACGATGCTCCGGTACTCCAGTGTAGGCAT } \\
3'-CAAAAGGGTCAGTGCTGCTACGAGGCCATGAGGTCACATCCGTA ${ }^{\mathbf{0}}$ GAATGCTTAA \\
GAACTCCGTCCGTACCATCGA-5'
\end{tabular} \\
\hline
\end{tabular}

Table 1: Substrates used in in vitro primer extension assays.

\subsection{Growth media}

YPD medium: 2\% D-glucose (Molar Chemicals Kft.), 2\% bacto peptone (MERCK), and 1\% yeast extract (MERCK) in distilled water, autoclaved for $25 \mathrm{~min}$ at $110^{\circ} \mathrm{C}$. For plates, $1.7 \%$ agar (agar bacteriological, Molar Chemicals Kft.) was added before autoclaving.

Synthetic complete (SC) medium: 2\% D-glucose, 0.17\% Difco yeast nitrogen base without amino acids and with ammonium sulphate and synthetic complete mixture. Synthetic complete mixture contained the following components (all from Sigma) weighed in as powder and added before autoclaving (final concentrations are indicated): adenine $40 \mathrm{mg} / \mathrm{liter}$, L-arginine 30 mg/liter, L-histidine 20 mg/liter, L-isoleucine 20 mg/liter, L-leucine 30 mg/liter, L-lysine-HCl $30 \mathrm{mg} /$ liter, L-methionine $20 \mathrm{mg} / \mathrm{liter}$, L-phenylalanine $50 \mathrm{mg} /$ liter, L-tryptophane 30 mg/liter, L-tyrosine $30 \mathrm{mg} /$ liter, uracil $20 \mathrm{mg} /$ liter, L-valine $100 \mathrm{mg} /$ liter. For dropout media, synthetic complete media with the respective amino acid left out was used.

\subsection{Sensitivity assays}

For Mycophenolic acid (MPA) and 6-azauracil (6-AU) sensitivity assays, 10x serial dilutions of overnight cultures grown in SC media were spotted on SC plates containing the respective amounts of MPA. Plates were incubated at $30^{\circ} \mathrm{C}$ for $4-5$ days. For UV sensitivity assays, serial 
dilutions were spotted on YPD plates, irradiated with the respective UV doses and incubated in the dark at $30^{\circ} \mathrm{C}$ for $2-3$ days.

\subsection{RNA analysis using reverse transcription quantitative real time PCR}

For induction of GAL10 and GAL1, yeast strains were grown in SC medium containing lactate (SC-L) medium at $30^{\circ} \mathrm{C}$ with vigorous shaking. At $\mathrm{A}_{600}: 0.5 \mathrm{MPA}$ was added to a final concentration of $70 \mu \mathrm{g} / \mathrm{ml}$. In experiments carried out with G1 arrested cells, first cells were synchronized in G1 phase by $50 \mathrm{ng} / \mathrm{ml} \alpha$-factor (Sigma) for $3 \mathrm{~h}$ at $\mathrm{A}_{600}: 0.4$ before MPA treatment, and were kept in G1 by $\alpha$-factor throughout the experiments. After $2 \mathrm{~h}$ incubation with MPA, galactose was added to a final concentration of $2 \% .1 \mathrm{~h}$ after induction cell pellet was quickly frozen at $-80^{\circ} \mathrm{C}$.

\begin{tabular}{|c|c|}
\hline Gene name & Primer sequence \\
\hline GAL1 Forward & GCTGCCTCTGTTTGCGGTGA \\
\hline TAF10 Forward & ACAGCCTGGCGTGCAGCAG \\
\hline UBC6 Forward & GGATGAGGGGGATGCGGCAAA \\
\hline GAL1 Reverse & AGTTGGTTGGGGCGGTTTCAA \\
\hline TAF10 Reverse & CAGCGCTACTGAGATCGTTCACCG \\
\hline UBC6 Reverse & ACGCTTGTTCAGCGCGTATTCTGT \\
\hline
\end{tabular}

Table 2: Sequences of oligonucleotides used in the real time RT-qPCR experiments.

Total RNA was purified using TRIzol Plus kit (Life Technologies) according to the manufacturer's protocol. On-column DNase treatment was performed for 20 min using PureLink DNase. Reverse transcription of $0.5 \mu \mathrm{g}$ RNA was performed using oligodT primer and Revert Aid first strand cDNA synthesis kit (Thermo Scientific). Real-time qPCR was performed with SYBR-Green detection method on Light Cycler 480 (Roche). Dissociation (melt) curves were analyzed after each run to confirm primer specificity. UBC6 and SED1 
genes were used for normalization (Shaw \& Reines, 2000; Teste et al, 2009). The sequences of oligonucleotides are shown in table 2.

\subsection{Dual Luciferase Assay}

Strains transformed with pID 723 and grown in uracil depleted SC -L medium were used to measure luciferase activity using the dual luciferase reporter assay system-E1910 (Promega). To measure the constitutive expression of renilla luciferase, before measurements logarithmically growing cells were counted using a Bürker chamber at $\sim \mathrm{A}_{600}: 0.7$ and activity was normalized to cell number. At indicated time points, $10 \mu \mathrm{l}$ of culture was added to $100 \mu 1$ of 1x Passive Lysis buffer. After allowing lysis for 10-15 seconds, a 10 $\mu$ l aliquot was used for luciferase assay measurements. $100 \mu \mathrm{l}$ of the renilla luciferase reagent was added and luminescence levels were measured using Thermoscientific Fluoroskan Ascent FL microplate Luminometer.

For dual luciferase assays, firefly luciferase expression was induced by $2 \%$ galactose at a culture density of $\sim \mathrm{A}_{600}: 0.7$ and cells were collected after $1 \mathrm{~h}$. Luciferase measurements were carried out according to the protocol using a Thermoscientific Fluoroskan Ascent FL microplate Luminometer. At indicated time points, $10 \mu 1$ of culture was added to $100 \mu 1$ of $1 \mathrm{x}$ Passive Lysis buffer. After allowing lysis for 10-15 seconds, a $10 \mu 1$ aliquot was used for luciferase assay measurements. $100 \mu \mathrm{l}$ of the firefly luciferase reagent (LARII) was added to the test sample followed by a 10 -s equilibration time and measurement of luminescence with a 10 -s integration time, For measuring activity of renilla luciferase, $100 \mu$ l of the Renilla luciferase reagent was added, which also quenches the firelfly luciferase (Stop \& Glo), 10-s equilibration time, and measurement of luminescence with a 10-s integration time. 


\subsection{In vivo transcription elongation assay}

Wild-type and mutant strains harboring the G-less cassette plasmid pCYC-LacZ (GLRO-long) were grown to $\mathrm{A}_{600}: 0.5$ in $\mathrm{SC}$-Leu at $30^{\circ} \mathrm{C}$. Transcription run-on assays were carried out as previously described (Steinmetz \& Brow, 2003; Tous et al, 2011). RNA was isolated using TRIzol (Life Technologies), digested with RNaseT1 and proteinase K (Thermo Scientific), precipitated with ethanol, resuspended in formamide gel loading buffer (Life Technologies) and resolved on $6 \%$ polyacrylamide gels containing $8 \mathrm{M}$ urea. Dried gels were analyzed with Typhoon TRIO Phosphorimager (GE Healthcare) using ImageQuant TL software (GE Healthcare) as described (Tous et al, 2011).

\subsection{Protein purification}

Wild type Pol $\eta$ and the Pol $\eta$ D30A mutant were overexpressed in N-terminal fusion with GST in yeast and purified in parallel on glutathione-Sepharose 4B beads following the protocol (Johnson et al, 2006). Yeast strains harboring the overexpression plasmid were induced with galactose, then collected by centrifugation and the cell wall disrupted by grinding in dry ice using a mortar and pestle. Cells were then resuspended in 1xBS buffer (50mM Tris-pH 7.0, $50 \mathrm{mM} \mathrm{Kcl}, 10 \%$ sucrose, $0.5 \mathrm{mM}$ EDTA) and ultra-centrifuged at $35.000 \mathrm{rpm}$ for 90 minutes at $4^{\circ} \mathrm{C}$. Cleared lysate was loaded onto a column packed with pre-equilibrated glutathione sepharose beads. Unbound proteins were washed off using 3 column volumes of high salt buffer (100mM Tris, $1 \mathrm{M} \mathrm{Nacl,} \mathrm{0.01 \%} \mathrm{NP40,} \mathrm{10 \%} \mathrm{glycerine),} 2$ column volumes of low salt buffer $(100 \mathrm{mM}$ Tris, $0.1 \mathrm{M}$ Nacl, $0.01 \%$ NP40, 10\% glycerine) and 2 column volumes of PreScission cleavage buffer (50mM Tris-pH7.5, 150mM Nacl, 1mM EDTA, 10\% glycerine, $0.01 \% \mathrm{NP} 40$ ). To obtain pure protein without GST tag, beads were incubated overnight at $4^{\circ} \mathrm{C}$ with gentle rocking with PreScission protease which cleaves the GST tag from the protein. 


\subsection{Primer extension assays}

Standard reactions $(5 \mu \mathrm{l})$ contained $25 \mathrm{mM}$ Tris $\mathrm{pH} 7.5,5 \mathrm{mM} \mathrm{MgCl}_{2}, 1 \mathrm{mM}$ dithiothreitol, bovine serum albumin $(100 \mu \mathrm{g} / \mathrm{ml}), 10 \%$ glycerol, $100 \mu \mathrm{M}$ dNTP or rNTP, and $16 \mathrm{nM}$ 5'Cy3labeled oligonucleotide primer annealed to an oligonucleotide template. Reactions were initiated by the addition of Pol $\eta$ at the indicated concentrations, incubated at $30^{\circ} \mathrm{C}$ for $10 \mathrm{~min}$ and quenched by the addition of $15 \mu$ l loading buffer containing $95 \%$ formamide, $18 \mathrm{mM}$ EDTA, $0.025 \%$ SDS, $0.025 \%$ bromophenol blue and $0.025 \%$ xylene cyanol. The reaction products were heated to $80^{\circ} \mathrm{C}$ for $5 \mathrm{~min}$, resolved on $10 \%$ polyacrylamide gels containing $8 \mathrm{M}$ urea and analyzed with a Typhoon TRIO Phosphorimager (GE Healthcare). The sequence of oligonucleotides and the structure of substrates are shown in Table1. For detection, primers labeled with the fluorophore indocarbocyanine (Cy3) at the 5'-ends were used.

\subsection{Determination of steady-state kinetic parameters}

Steady-state kinetics of RNA and DNA primer extensions were measured using the same buffer as in the standard reactions. Reaction conditions were optimized by time course analysis of different enzyme/substrate ratios. Reactions contained 20 nM 5'Cy3-labeled hybridized RNA or DNA primer, $1 \mathrm{nM}$ of Poln, and the concentrations of rNTPs varied from 0.01 to $4 \mathrm{mM}$. Reactions were initiated by adding the corresponding rNTPs at the indicated concentrations and incubated at $30^{\circ} \mathrm{C}$ for 2 to $60 \mathrm{~min}$, then quenched and resolved on $10 \%$ polyacrylamide gels containing $8 \mathrm{M}$ urea. The intensity of the gel bands corresponding to the substrate and the product were quantified with Typhoon TRIO Phosphorimager (GE Healthcare) using ImageQuant TL software (GE Healthcare) and the observed rates of nucleotide incorporation were plotted as a function of rNTP concentration. The data were fit by nonlinear regression using GraphPad Prism 6 to the Michaelis-Menten equation describing a hyperbola, $v=\left(V_{\max }\right.$ $\mathrm{X}[\mathrm{rNTP}] /\left(K_{m}+[\mathrm{rNTP}]\right)$. The turnover number $\left(k_{c a t}\right)$ and Michaelis-Menten constant $\left(K_{m}\right)$ 
steady-state parameters were obtained from the fit and were used to calculate the efficiency of extension by using the following equation: $f_{\text {ext }}=\left(k_{\text {cat }} / K_{m}\right)_{\mathrm{RNA}} /\left(k_{\text {cat }} / K_{m}\right)_{\mathrm{DNA}}$. 


\subsection{Results}

\subsection{Polymerase eta confers resistance to transcription elongation inhibitors}

MPA is a transcription elongation inhibitor drug that inhibits IMP (Inosine-5'-monophosphate dehydrogenase) dehydrogenase and thereby leads to a reduction of intracellular GTP levels, which leads to an inhibition of transcription elongation. Sensitivity to mycophenolic acid is a phenotype characteristic of yeast with mutations in the transcription elongation machinery and RNA polymerase II subunits (Archambault et al, 1992; Costa \& Arndt, 2000; Davie \& Kane, 2000; Hartzog et al, 1998; Hemming et al, 2000; Ishiguro et al, 2000; Lennon et al, 1998; Orphanides et al, 1999; Powell \& Reines, 1996; Wu et al, 1996). DST1, encoded by TFIIS in yeast is one well known transcription elongation factor with MPA sensitive phenotype (Exinger \& Lacroute, 1992; Nakanishi et al, 1992).

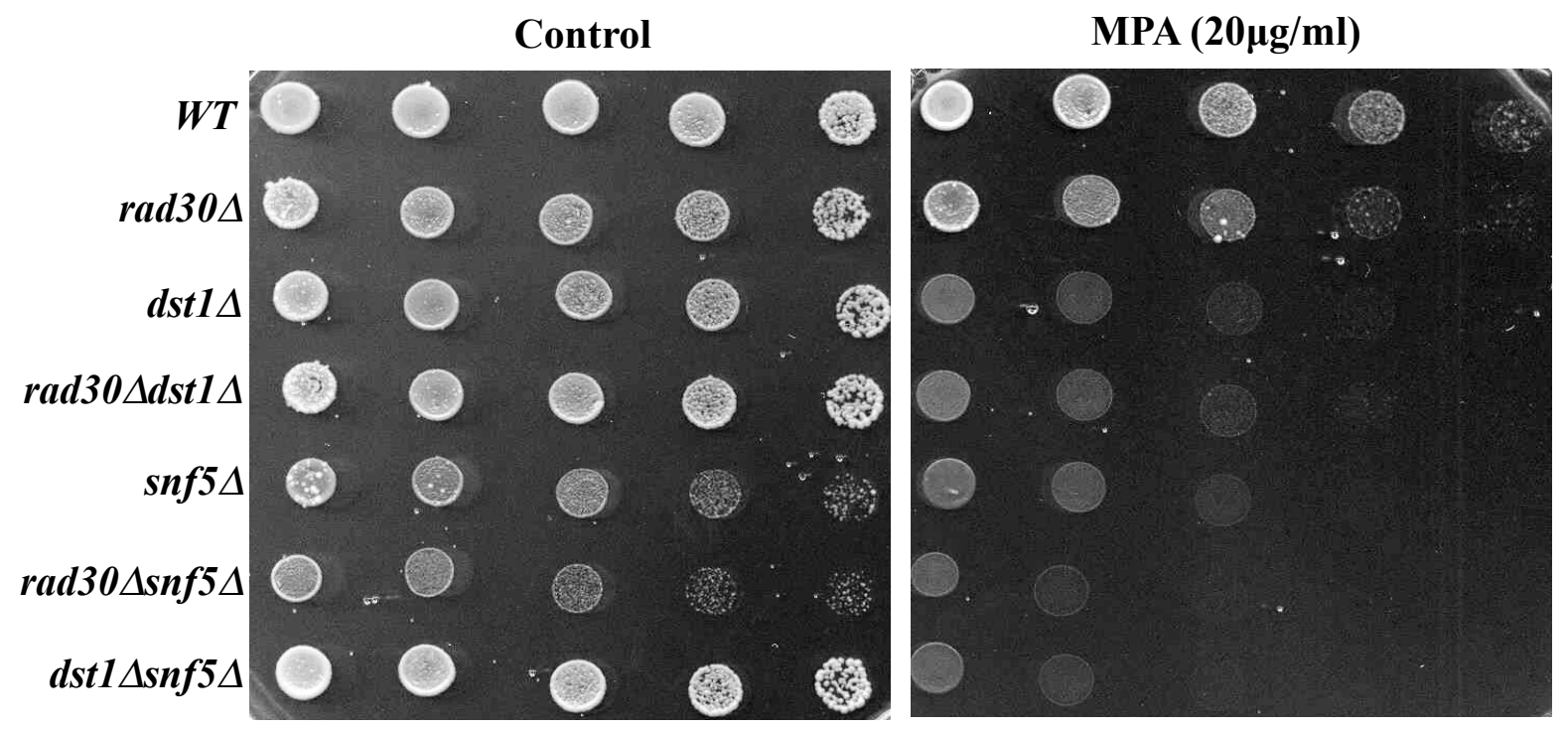

Figure 7.Sensitivity of indicated strains to the transcription elongation inhibitor drug mycophenolic acid. 10-fold serial dilutions were spotted on synthetic complete media plates.

When we examined the sensitivity of yeast deletion strains to MPA, we discovered that deficiency of Pol $\eta$ confers a sensitive phenotype. As can be observed in Figure 7, at a 
concentration of $20 \mu \mathrm{g} / \mathrm{ml}$, rad30 deletion strain compared to wild type has a sensitive phenotype.

Deletion of $D S T 1$, a transcription elongation factor, also confers a sensitive phenotype as expected. However, a double deletion strain, rad30 $\Delta d s t 1 \Delta$ has no additional sensitivity phenotype on the yeast strain indicating that it could be an epistatic relationship between the two genes and they might function in the same pathway. We also examined the sensitivity of $\operatorname{rad} 30 \Delta s n f 5 \Delta$ and $d s t 1 \Delta s n f 5 \Delta$ deletion strains on MPA containing medium. While snf5 $\Delta$ deletion confers a highly sensitive phenotype, additional deletion of $R A D 30$ makes the strain hypersensitive, indicating that Rad30 and Snf5 might be acting in separate pathways affecting transcription.

Similarly, a $d s t 1 \Delta \operatorname{snf5} \Delta$ double deletion strain also shows hypersensitive phenotype indicating that these two genes function in separate pathways. Overall, the results indicate that the transcriptional function of $\mathrm{Pol} \eta$ might be distinct from the transcriptional function of Snf5 but similar to Dst1.

\subsection{Induced synthesis of GAL10 mRNA is defective in Pol $\eta$ deficient strain}

The results we obtained with MPA sensitivity assay led us to further investigate if Pol $\eta$ indeed has a role to play in transcription. For this, we examined the transcription of a galactose

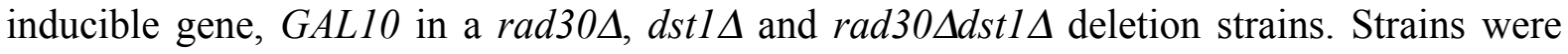
grown in lactic acid containing medium, treated with MPA for 2 hours and then induced with galactose. RNA was prepared from the samples and reverse transcribed. The level of GAL10 cDNA was determined with qPCR and the level of SED1, a constitutively expressed cell-wall protein was used as internal control. It can be seen in Figure 8 that deletion of $R A D 30$ had an effect on transcription of GAL10, the level of GAL10 mRNA has dropped to $70 \%$ of wild type. 
Deletion of DST1 results in the level of GAL10 mRNA to drop to $40 \%$ of wild type, but additional deletion of $R A D 30$ in $d s t 1 \Delta$ does not lead to a further defect in transcription.

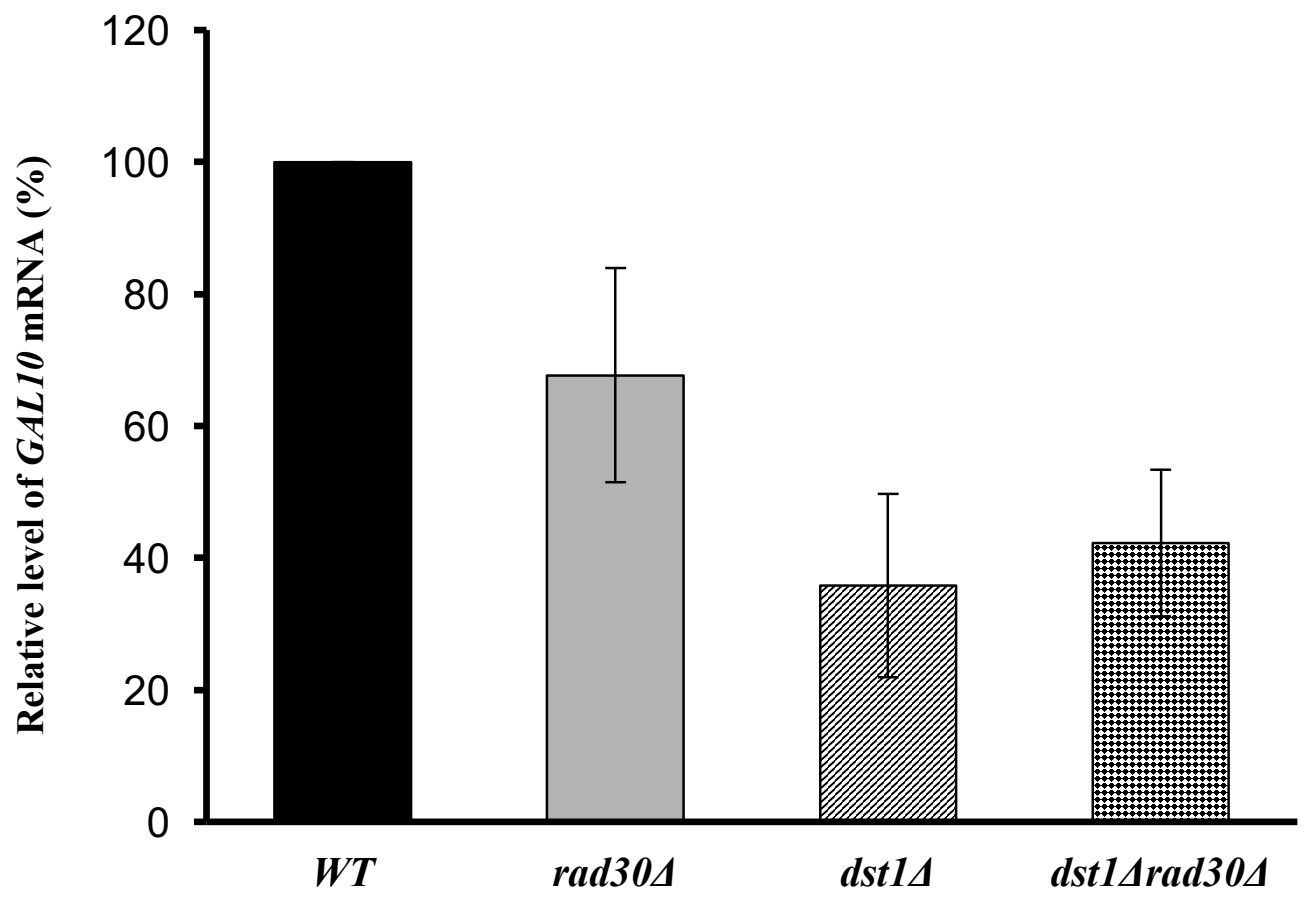

Figure 8.Induced synthesis of GAL10 mRNA as determined by real time RT-qPCR. The values obtained represent the mean of five experiments.

These results are in agreement with the MPA sensitivities of the strains indicating that Pol $\eta$ indeed has a role to play in transcription and it might act together with Dst1.

\subsection{Expression of luciferase genes is defective in Pol $\eta$ deficient strain}

To obtain additional evidence to confirm the transcriptional function of Rad30, we used dual luciferase assay. Reporter genes provide easy and efficient methods for the indirect measurement of relative rates of transcription. We made use of the commonly used reporter genes, firefly (Photinus pyralis) luciferase and sea pansy (Renilla reniformis) luciferase genes (McNabb et al, 2005).

We constructed a plasmid for simultaneously measuring the activity of firefly and renilla luciferase genes by cloning the firefly luciferase gene downstream of an inducible GAL1 
promoter and renilla luciferase gene downstream of a constitutive glyceraldehyde-3-phosphate dehydrogenase (GPD) promoter.

A

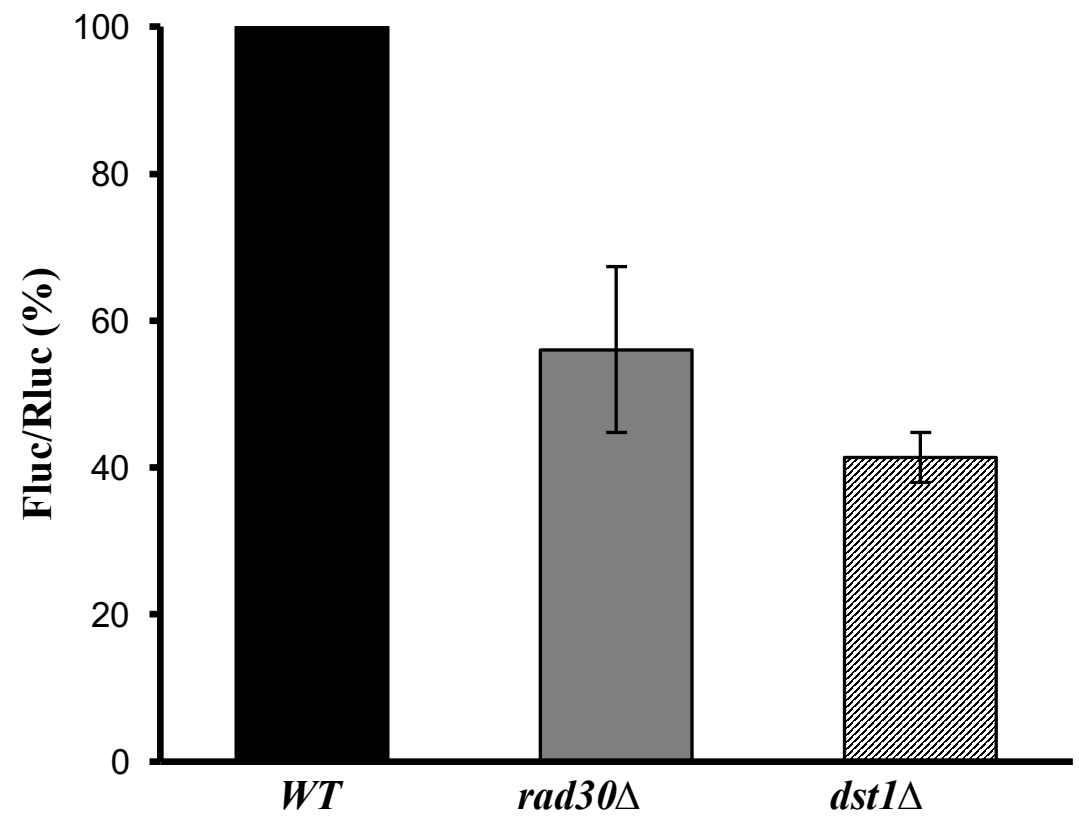

$\mathrm{B}$

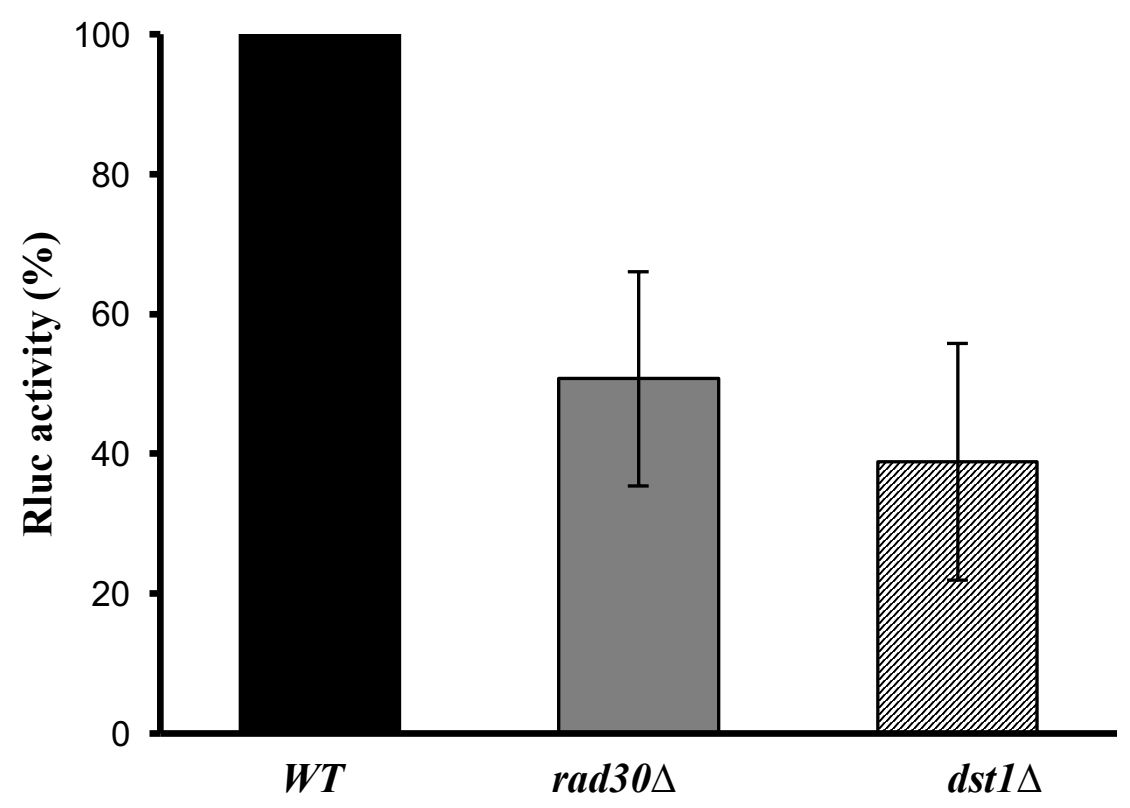


Figure 9. A. Dual luciferase assay to measure the galactose induced expression of firefly luciferase gene relative to the renilla luciferase, and $\mathbf{B}$. Measurement of constitutive expression of renilla luciferase gene driven by $G P D$ promoter. The values in both cases represent mean of five experiments.

We performed dual luciferase assay, where galactose induced expression of firefly luciferase gene was measured using the constitutive expression of renilla luciferase gene as a control. As can be noted in Figure 9A, luciferase levels dropped to $60 \%$ of wild type level in a rad30 $\Delta$ deletion strain and to about $40 \%$ in a $d s t 1 \Delta$ deletion strain. Similar results can be noted in case of measuring the constitutive expression alone driven by a strong GPD promoter and measuring the renilla luciferase activity levels alone (Figure 9B).

The results show that both in case of induced and constitutively expressed genes, transcription is defective in the absence of Pol $\eta$.

\subsection{Transcription elongation role of Pol $\eta$ as evidenced by in vivo transcription elongation} assay (GLRO assay)

All the results obtained above indicated that Pol $\eta$ has a certain role to play in transcription. Sensitivity to MPA, which indicates a defect in transcription elongation together with epistatic relationship with a known transcription elongation factor, Dst1, led us to verify the transcription elongation role by performing an in vivo assay for direct analysis of elongation on chromatin using G-less-based run-on (GLRO) assay (Tous et al, 2011).

In this experiment, we used the GLRO-long plasmid (Figure 10A), which contains two G-less cassettes of $262 \mathrm{nt}$ and $132 \mathrm{nt}$ separated by a 2-kb fragment of the lac $Z$ gene. The length and high GC content of lacZ makes transcription through this sequence poorly efficient in mutants impairing elongation. Transcription-elongation efficiency was measured as the ratio of ${ }^{32} \mathrm{P}$ incorporated into the 132-nt-long versus the 262-nt-long G-less cassette. After in vivo labelling of the nascent mRNA in the run-on reaction, the resulting transcripts were purified and treated with RNase T1 to degrade all G-containing sequences, leaving the two G-less cassettes as two intact fragments that were resolved by polyacrylamide gel electrophoresis. 
It is very clear from Figure 10 that deletion of $R A D 30$, has a direct effect on the transcription of the GLRO cassette, where that levels have dropped to $60 \%$ of wild type (Figure 10). Spt4 is a transcription elongation factor which is shown to be defective in transcription elongation and the efficiency of transcription elongation in $\operatorname{spt} 4 \Delta$, is about $20 \%$ of wild type levels which is similar to the results obtained in the study by Tous and coworkers (Tous et al, 2011).

A

\section{GLRO-long}

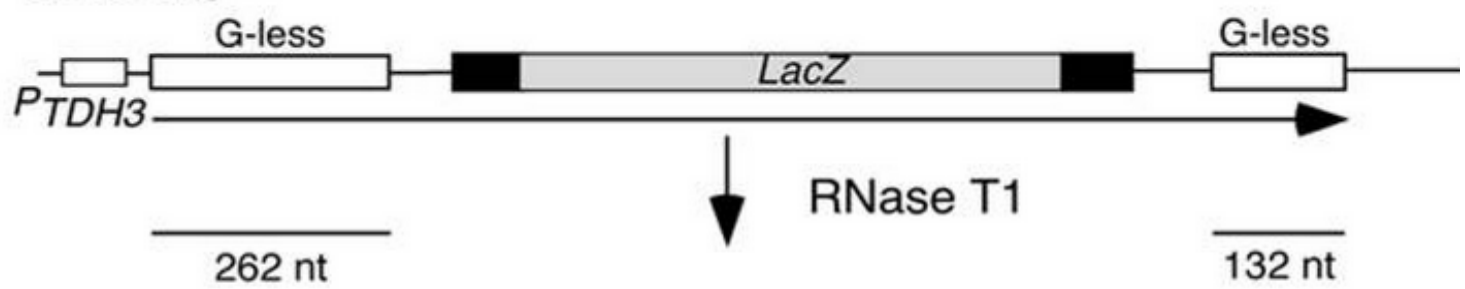

B
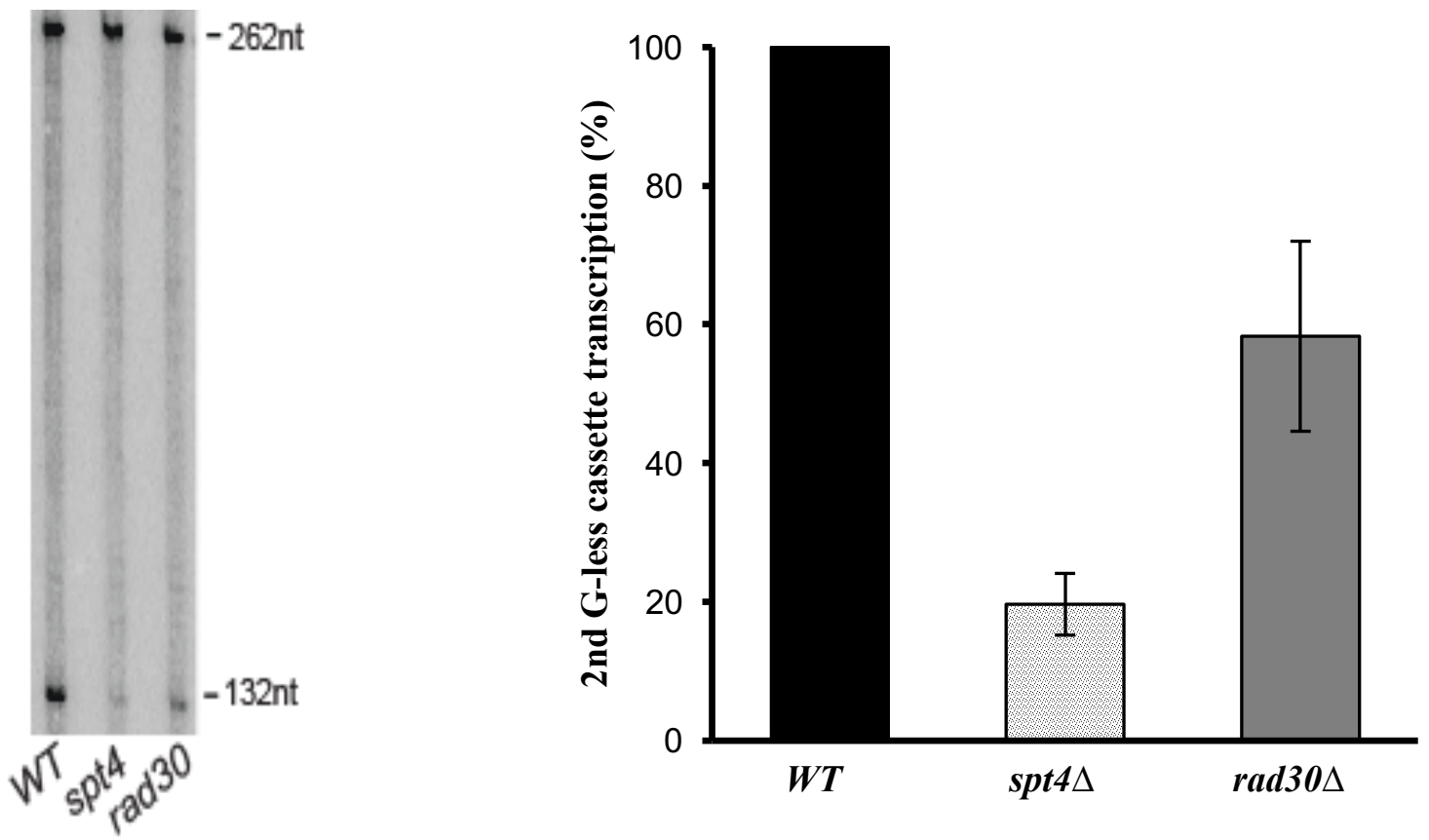

Figure 10. A. Design of the GLRO-long plasmid. (Adapted from Tous et al, 2011) B. GLRO assay to measure transcription elongation efficiency in different mutants as indicated. The gel picture shows the G-less cassette transcripts after digestion with RNase T1. The graph on the right shows the quantitation values from the gel picture on the left. The values in the graph are a mean of three experiments. 


\subsection{The catalytic activity of Pol $\eta$ is necessary for its role in transcription}

The results presented so far gave a clear evidence for the role of Polymerase $\eta$ in transcription elongation. We further investigated if Pol $\eta$ has just a structural role in transcription elongation or its polymerase activity is involved as well in its transcription elongation function. For this experiment, we used the D30A point mutation in the active centre of Pol $\eta$ and it is know to abolish the DNA polymerase activity completely (Kondratick et al, 2001; Trincao et al, 2001). In a rad30 $\Delta$ strain, we re-integrated either a WT Rad30 or rad30 D30A encoding DNA sequences. Then, we tested the strains for sensitivity to UV irradiation and 6-AU (Figure 11). The results show that, while reintegration of WT Rad30 resulted in rescue of both UV and 6AU sensitivities, reintegration of rad30 D30A mutant rescued neither the UV nor the 6-AU sensitivity of rad30 $\Delta$ strain.

The results clearly show that polymerase domain of Pol $\eta$ is important for its function in transcription.

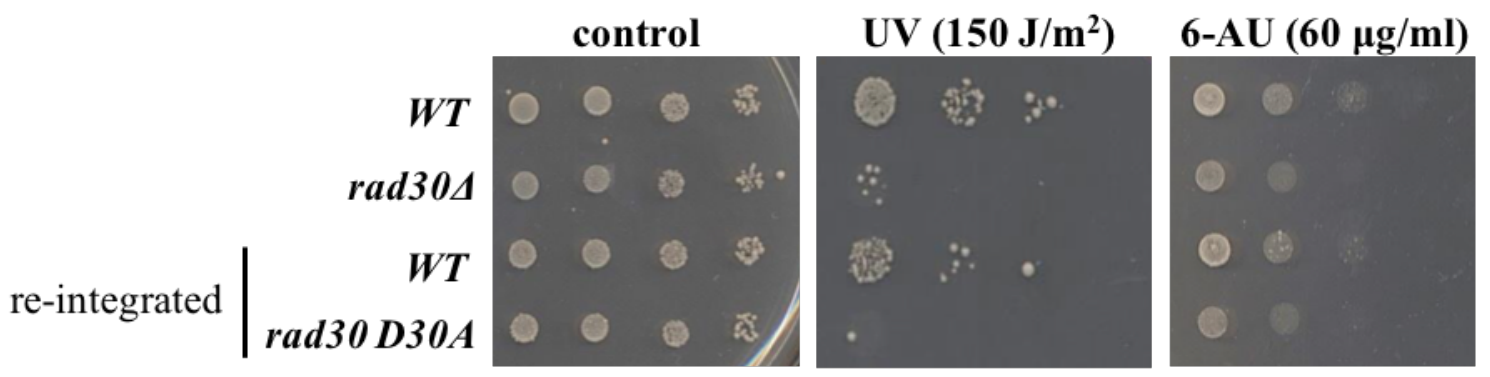

Figure 11.UV and MPA sensitivities of Pol $\eta$ D30A mutant. 10-fold serial dilutions of overnight grown cultures were spotted on media incubated at $30 \mathrm{C}$ as described in materials and methods and then analysed for phenotype. 
To verify if the polymerase domain of Pol $\eta$ is indeed necessary for its transcriptional function, we also performed performed qPCR experiments to measure the level of GAL1 and GAL10 using the Pol $\eta$ D30A mutant. (Figures 12 \& 13). Consistent with the UV and 6-AU sensitivity results, WT Rad30 also rescued the defect in induced synthesis of GAL1 and GAL10 genes observed in rad30 $\Delta$ whereas, $\operatorname{Rad} 30 \mathrm{D} 30 \mathrm{~A}$ mutant negatively affected the activation of $G A L 1$ and GAL10 genes

All results with the Pol $\eta \mathrm{D} 30 \mathrm{~A}$ mutant point to the fact that, the catalytic domain of Pol $\eta$ which controls its polymerase activity is necessary for its transcriptional role.

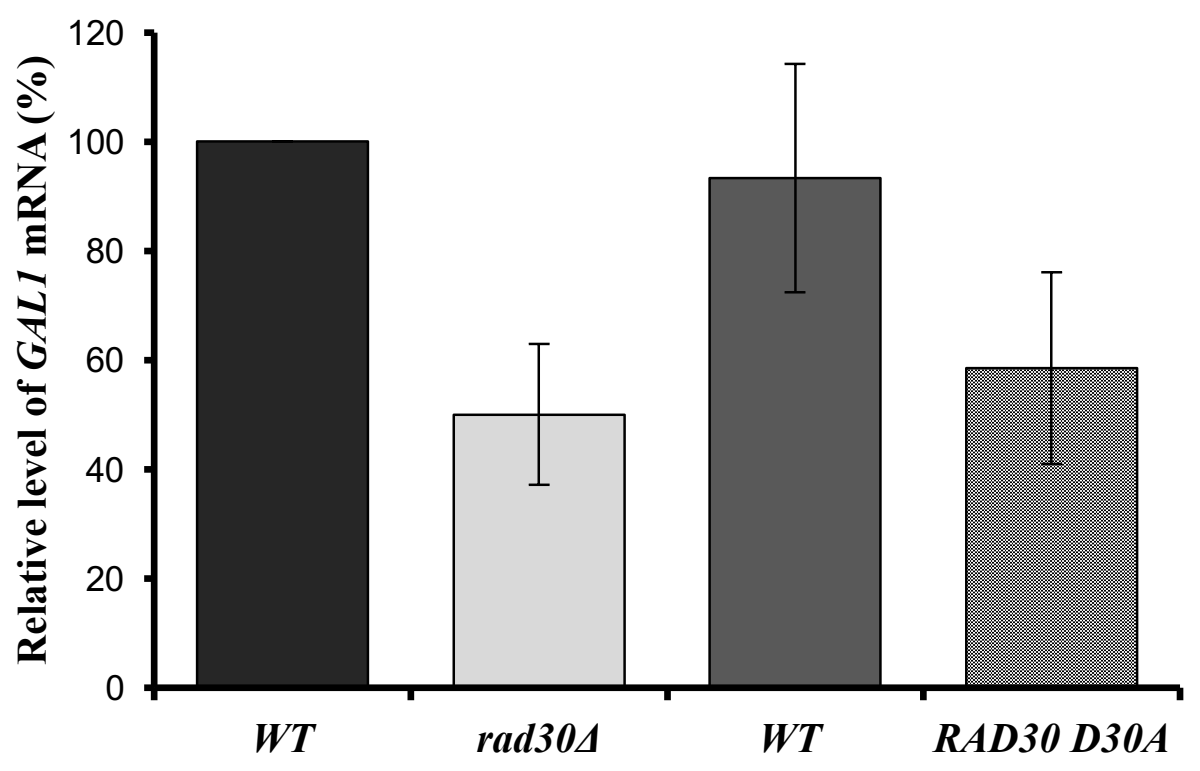

Figure 12. Induced level of GAL1 measured in Pol $\eta$ D30A mutant. The values represent a mean of five experiments 


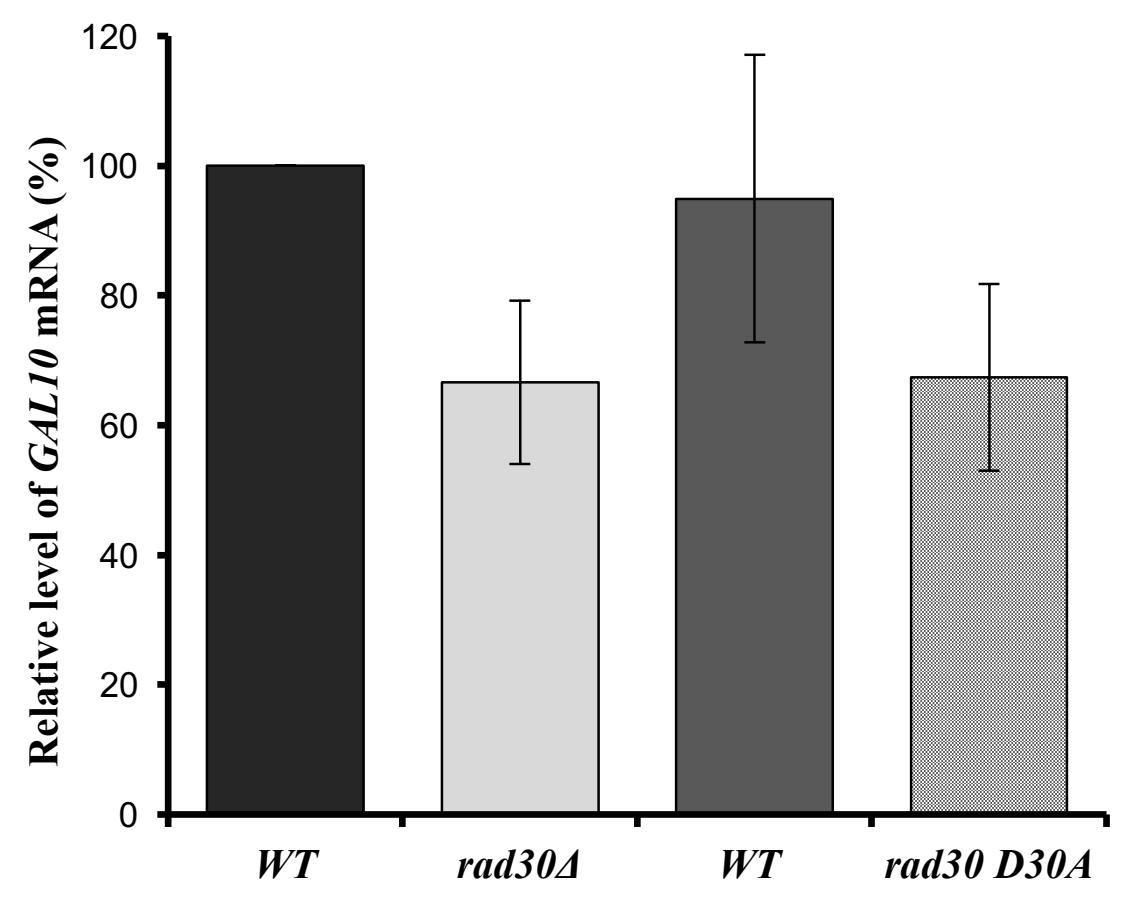

Figure 13.Induced level of GAL10 measured in Pol $\eta$ D30A mutant. The values represent a mean of five experiments.

\subsection{Pol $\eta$ is capable of incorporating ribonucleotides in vitro opposite to undamaged and damaged DNA templates}

The active centre of the polymerase which controls its DNA polymerase activity is required for its transcription elongation function. Pol $\eta$ is known to function as a translesion DNA polymerase upon DNA damage. Based on this information, we hypothesized that Pol $\eta$ can insert ribonucleotides during transcription elongation opposite to damaged DNA. To verify our hypothesis, we performed an in vitro assay for ribonucleotide incoportation into RNA.

For the assay, we purified Pol $\eta$ and Pol $\eta$ D30A proteins in yeast by using the over expression plasmids pID206 and pID797, respectively. $200 \mathrm{ng}$ of each protein was analyzed on $8 \%$ polyacrylamide gel. The molecular weight of the purified proteins matched with the calculated molecular weight of $71.5 \mathrm{kda}$ (Figure14). 


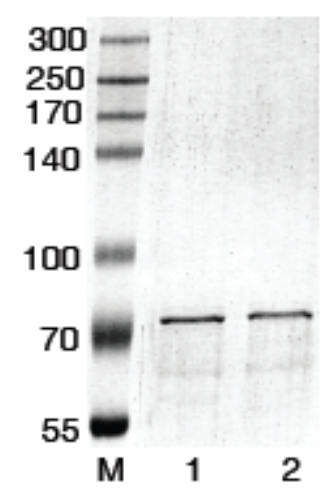

Figure 14. Coomassie stained SDS-PAGE shows purification of yeast Pol $\eta$ (1) and Pol $\eta$ D30A (2).

By using purified Pol $\eta$ and Pol $\eta$ D30A we performed in vitro DNA synthesis and RNA synthesis assays. Substrates used in the in vitro primer extension assays are listed in Table 1. In the presence of all four dNTPs Pol $\eta$ was able to incorporate nucleotides and extend the DNA primer to the end of template as it is expected (figure 15A) As a significant outcome, we discovered that Pol $\eta$ was also capable of extending the RNA primer though at higher enzyme concentrations as in the DNA pimer extension (Figure 15B). To rule out the possibility that the observed RNA synthesis activity is because of any contaminating RNA polymerase activity in the purified Pol $\eta$, we used Pol $\eta$ D30A mutant to perform the primer extension assays.

A

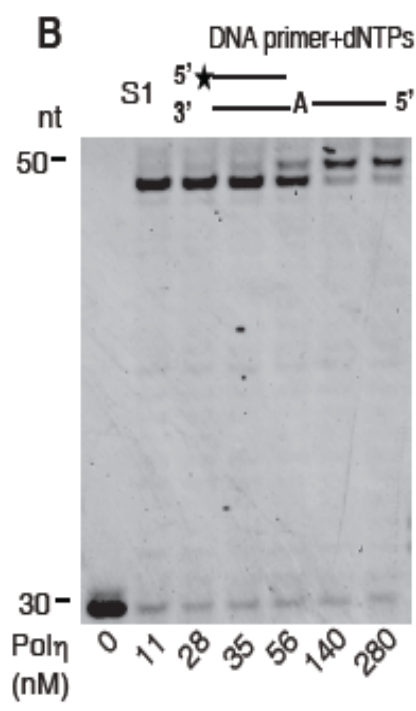

B

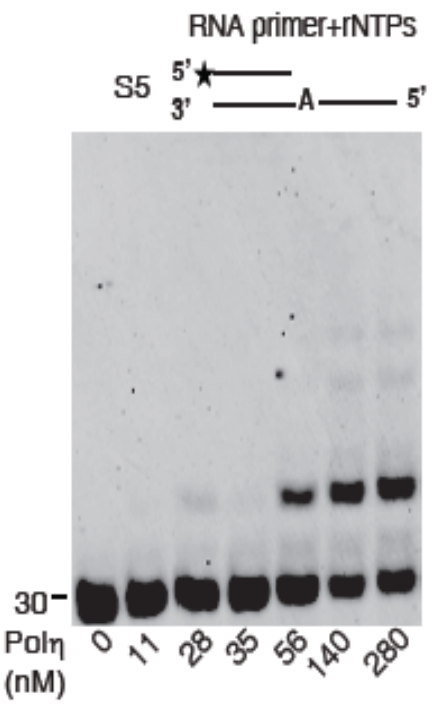

C

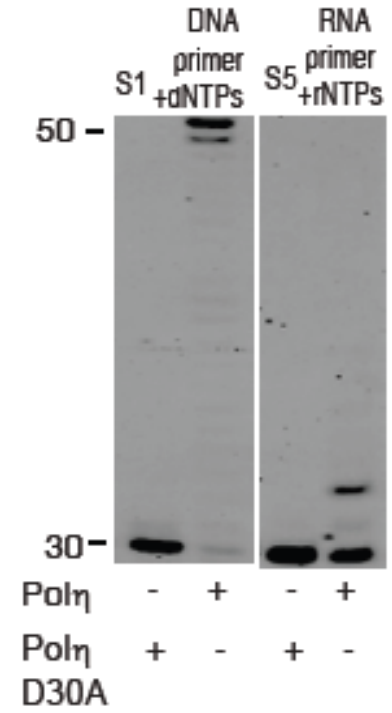


Figure 15. A. DNA and RNA primer extension of Pol $\eta$. Reactions were carried out with increasing concentrations of Pol $\eta$, indicated at the bottom, in the presence of all four dNTPs (left) or rNTPs (right). The structures of the substrates are shown at the top. The length of primer (30 bp) and product (31 bp or $50 \mathrm{bp}$ ) are indicated. B. Primer extension assays using Pol $\eta$ and Pol $\eta$ D30A mutant.

As can be observed in Figure 15C, primer extension activity both in case of DNA primer and RNA primer can be noticed only when wild type Pol $\eta$ is used in the assay. This experiment validates the fact that the observed RNA snythesis activity of Pol $\eta$ is intrinsic to the enzyme.

We also performed a primer extension assay with either a DNA primer or RNA primer and increasing rNTP concentrations. We noticed that incorporation of ribonucleotides is specific to RNA primer (Figure 16B) and Pol $\eta$ is very inefficient in incorporating ribonucleotides into a DNA primer (Figure 16A).

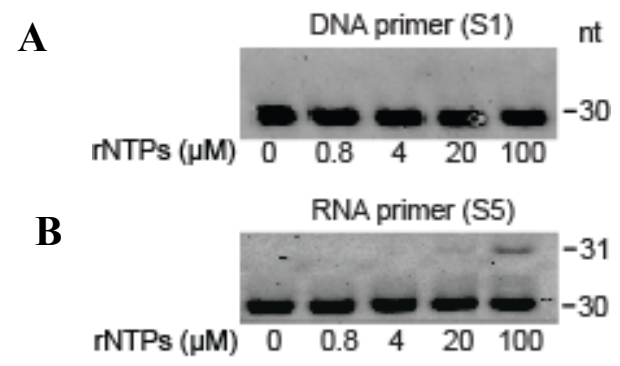

Figure 16. rNTP incorporation into DNA (A) and RNA (B). Pol $\eta(56 \mathrm{nM})$ was incubated in the presence of increasing concentrations of all four rNTPs, as indicated at the bottom, with either DNA (A) or RNA (B) primer containing substrates.

Based on the results obtained so far, in vivo experiments showed that Pol $\eta$ plays a role in transcription elongation and that the active centre of the enzyme which controls its catalytic activity is necessary for its role. In vitro results also showed that the active centre of Pol $\eta$ is necessary for its ability to perform ribonucleotide synthesis. Taking all these into account, we hypothesized that under normal growth conditions Pol $\eta$ acts as a transcription elongation factor and might be part of the transcription elongation machinery. But, when damage 
conditions are encountered, Pol $\eta$ might incorporate ribonucleotides opposite to damage and help transcription proceed further without stalling.

A

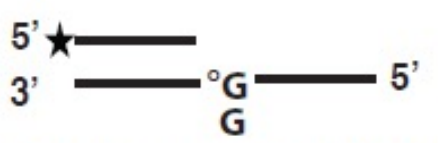

DNA primer+ dNTPS

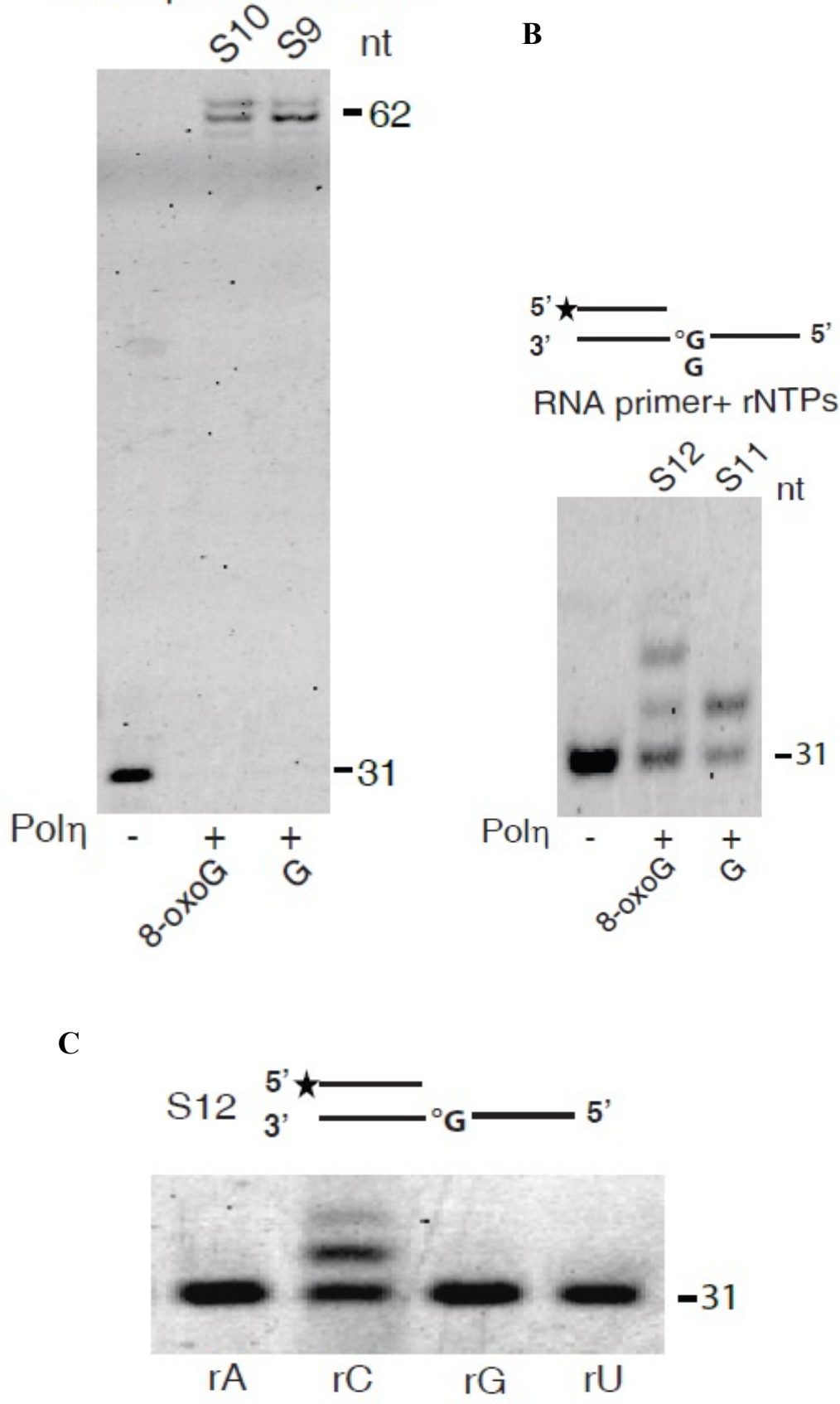


Figure 17. A. DNA and B. RNA extension by Pol $\eta$ opposite 8-oxoG. Reactions were carried out with $1.6 \mathrm{nM}$ DNA (left) or RNA (right) primer containing substrates and $28 \mathrm{nM}$ Pol $\eta$ in the presence of all four dNTPs (left) or rNTPs (right) $(100 \mu \mathrm{M})$. C. RNA primer extension by Pol $\eta$ in the presence of individual NTP $(4 \mathrm{mM})$ opposite to 8 -oxoG.

8- oxoguanine is one of the most common DNA lesions resulting from reactive oxygen species.

So, by using a template strand containing 8-oxoguanine, and using both DNA and RNA primer to perform primer extension assays, we noticed that Pol $\eta$ is capable of incorporating ribonucleotides opposite to damaged DNA (Figure 17A\&B). To verify if Pol $\eta$ carries out ribonucleotide incorporation opposite to damaged DNA in an error-free manner, we performed primer extension assay using 8-oxoguanine containing template and individual ribonucleotides. As can be observed in Figure 17C, though a very high concentration of individual rNTPs were used, Pol $\eta$ inserts only rCTP opposite to 8-oxoguanine.

\subsection{Analysis of ribonucleotide incorporation activity of Pol $\boldsymbol{\eta}$ by steady state kinetics}

To check the in vivo significance of ribonucleotide incorporation activity of Pol $\eta$ and to rule out that ribonucleotide incorporation is just because of the open conformation of active site of the polymerase, we performed steady state kinetic analysis experiments.

When an enzyme reacts with substrate, sudden burst or increase in product formation is observed. Once all the active sites of the enzyme are occupied by the substrate, product formation attains a steady state. Steady state kinetics allows the calculation of Kcat which is turnover number of the enzyme and Km (Michaelis-Menten constant) which is substrate concentration at which reaction rate is half-maximum. The constant $\mathrm{Kcat} / \mathrm{Km}$ is a measure of how efficiently an enzyme converts a substrate into product. In this case, we measured how efficient is RNAPII in using RNA primer or DNA primer as its substrate for incorporating rNTPs. 
In vitro reactions containing a single incoming ribonucleotide of increasing concentrations and using DNA or RNA primers, and templates in all four sequence variations in the position opposite the first insertion were performed (Figures 18 and 19). Each of the experiments were performed at least 3 times and the incorporation efficiencies were calculated by quantifying the product and plotting them with velocity (nM/Min) incorporated on $\mathrm{Y}$-axis and concentration of incoming ribonucleotide on $\mathrm{X}$-axis using a Michaelis-Menten equation. The $\mathrm{Kcat}$ and $\mathrm{Km}$ values and the relative efficiency of incorporation into RNA as opposed to DNA are presented in Table 2. Pol $\eta$ inserted rNTPs into RNA primers one order of magnitude more efficiently compared to DNA primers (Table 1) proving that Pol $\eta$ recognized RNA as its substrate and rNTP incorporation into RNA was specific. We note that though the $K_{m}$ values for RNA extension with rNTPs were high, they were still in the range of the intracellular concentrations of rNTPs (Nick McElhinny et al, 2010). These results strongly supported the in vivo significance of rNTP incorporation into RNA by Pol $\eta$. 
A<smiles>[AsH3]I=[13CH]I</smiles>

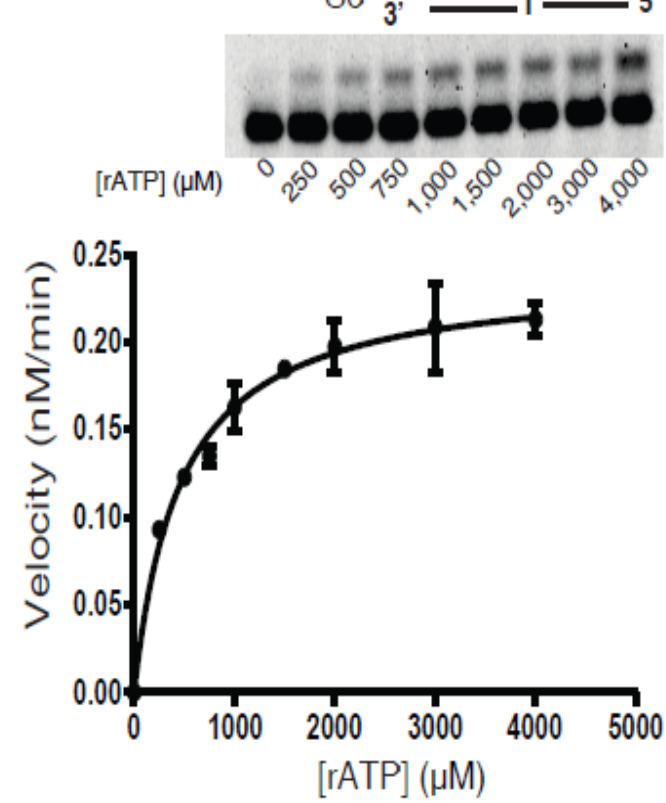

C<smiles></smiles>

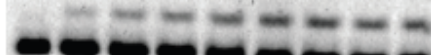

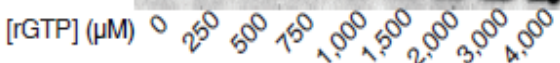

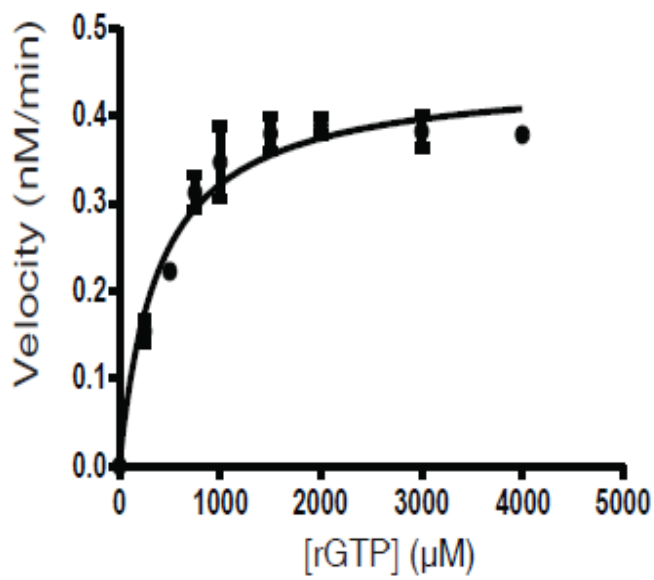

B<smiles>CC([SiH3])=[AsH2][SiH3]</smiles>

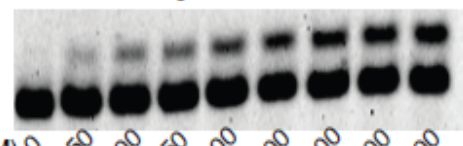

[RTTP] (NM) 0 v

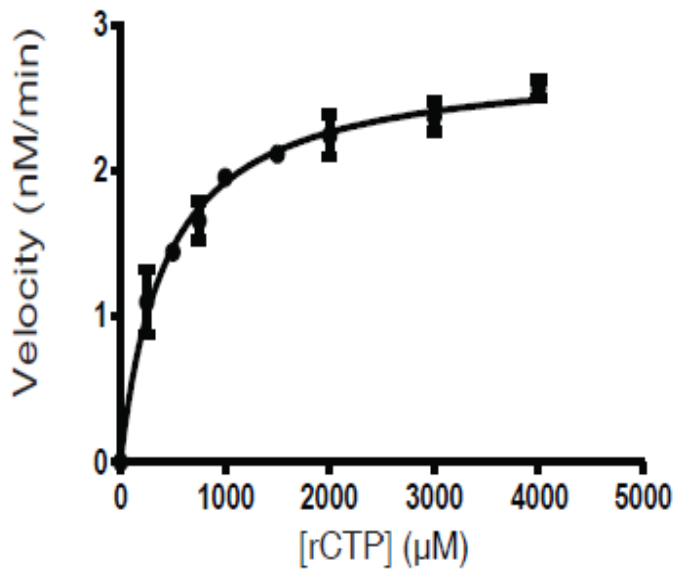

D
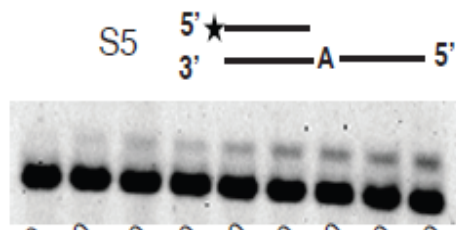

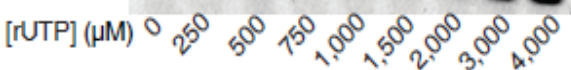

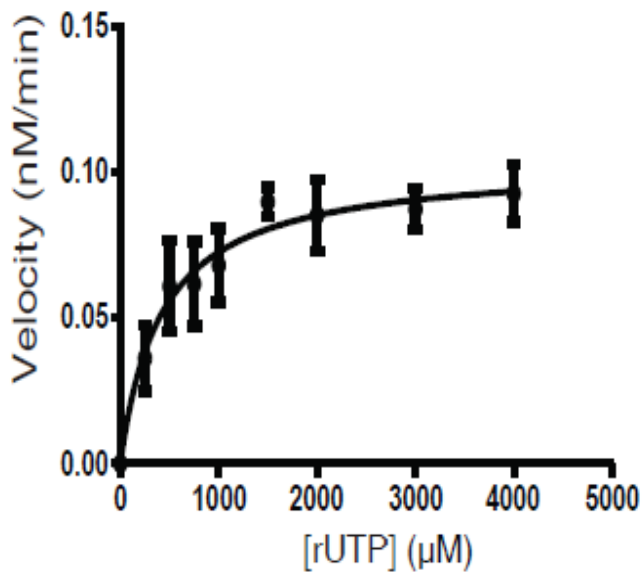

Figure 18. Steady-state kinetic analysis of RNA primer extension by Pol $\eta$ with rNTPs. Pol $\eta(1 \mathrm{nM})$ was incubated with $20 \mathrm{nM}$ of templates in the presence of increasing concentrations of the single incoming rNTP, A. rATP B. rCTP C. rGTP, D. rUTP as indicated under the gel pictures. The quenched samples were analyzed by denaturing polyacrylamide gel electrophoresis, and for each rNTP the rate of incorporation is plotted as a function of rNTP concentrations. The data were fit to the MichaelisMenten equation. 
A $\mathrm{S} 2$ $3^{\prime}$ T 5 ,
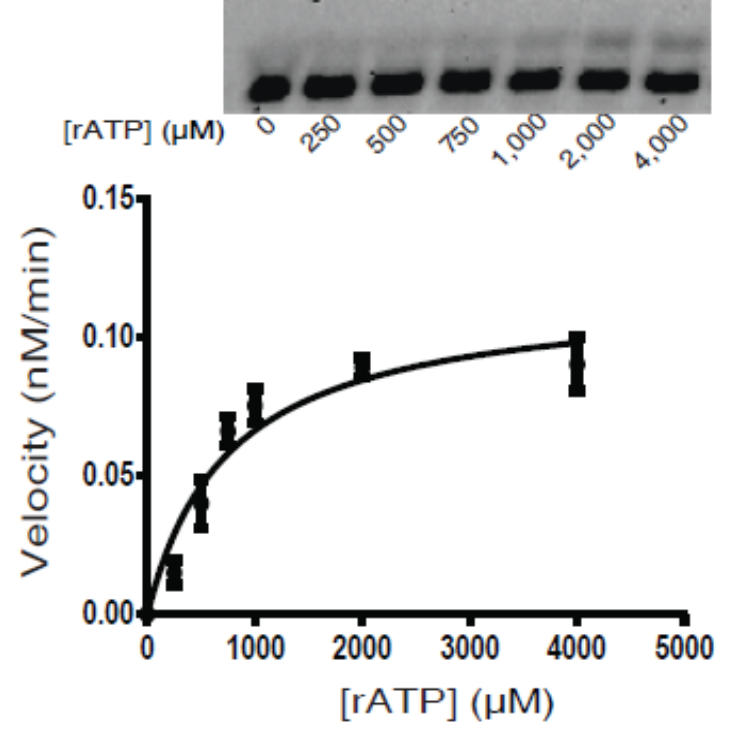

C
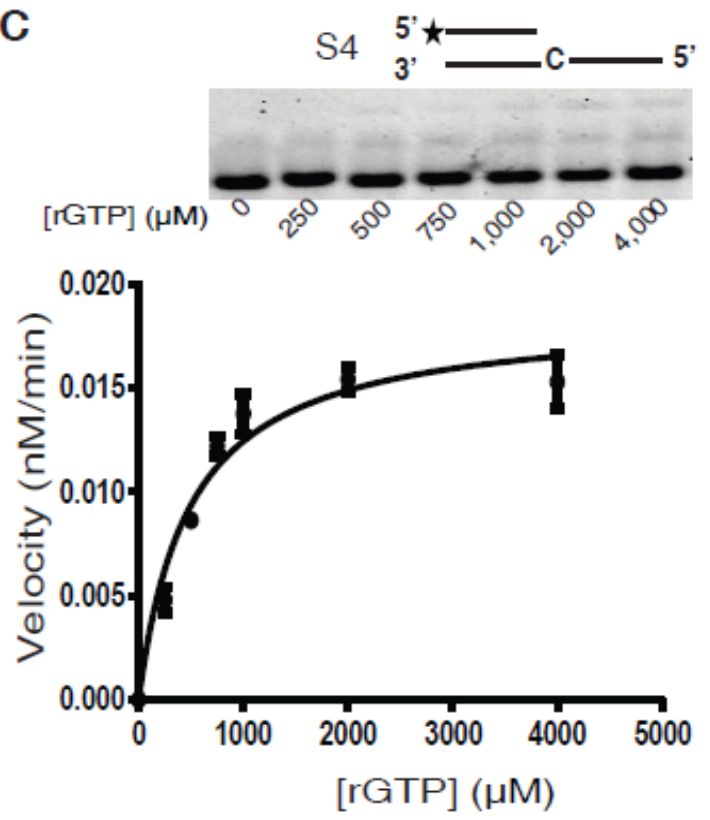

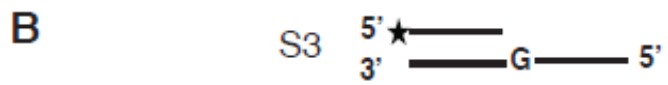

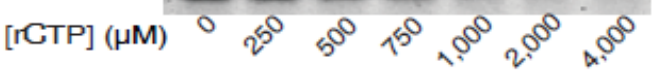

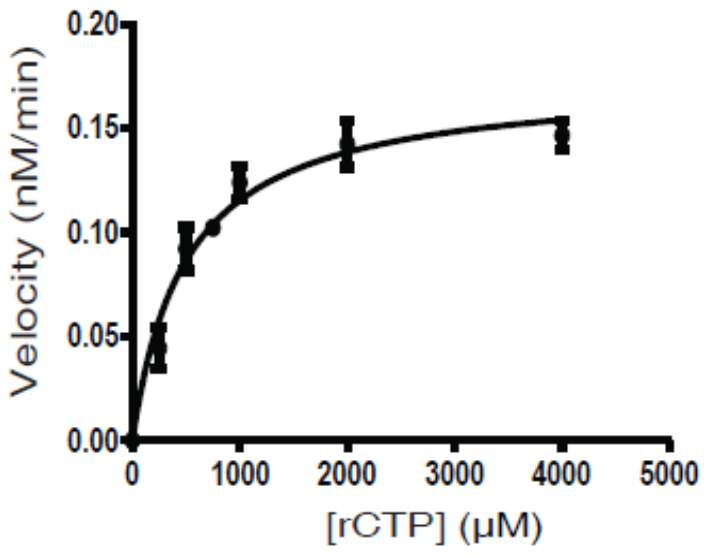

D

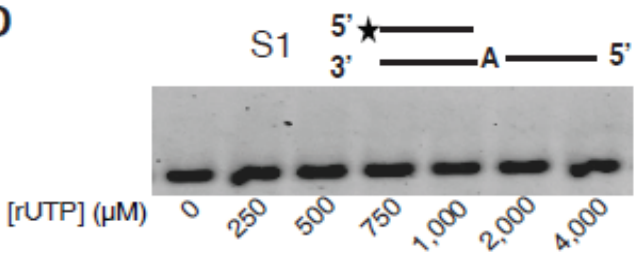

Figure 19. Steady-state kinetic analysis of DNA primer extension by Pol $\eta$ with rNTPs. Pol $\eta(1 \mathrm{nM})$ was incubated with $20 \mathrm{nM}$ of templates in the presence of increasing concentrations of the single incoming rNTP, A. rATP B. rCTP C. rGTP, D. rUTP as indicated under the gel pictures. The quenched samples were analyzed by denaturing polyacrylamide gel electrophoresis, and for each rNTP the rate of incorporation is plotted as a function of rNTP concentrations. The data were fit to the MichaelisMenten equation. 


\begin{tabular}{|c|c|c|c|c|c|c|}
\hline Primer & $\begin{array}{c}\text { Insertion } \\
\text { opposite }\end{array}$ & $\begin{array}{c}\text { Incoming } \\
\text { Riboucleotide } \\
\end{array}$ & $\begin{array}{c}\text { Kcat } \\
(\text { min-1) }\end{array}$ & $\begin{array}{c}\mathbf{K m} \\
(\mu \mathrm{M})\end{array}$ & Kcat $/ \mathbf{K m}$ & $\begin{array}{c}\text { Relative } \\
\text { efficiency }\end{array}$ \\
\hline RNA & $\mathrm{T}$ & ATP & $\begin{array}{c}0.2394 \pm \\
0.0065\end{array}$ & $\begin{array}{c}466.4 \pm \\
47.29\end{array}$ & 5.13E-04 & 3.34 \\
\hline RNA & G & СТP & $\begin{array}{l}2.758 \pm \\
0.06217\end{array}$ & $\begin{array}{c}438.3 \pm \\
37.52\end{array}$ & $62.9 \mathrm{E}-04$ & 18.26 \\
\hline RNA & $\mathrm{C}$ & GTP & $\begin{array}{c}0.4487 \pm \\
0.01485\end{array}$ & $\begin{array}{c}393.7 \pm \\
52.04\end{array}$ & 11.4E-04 & 30.24 \\
\hline RNA & A & UTP & $\begin{array}{l}0.1032 \pm \\
0.005715\end{array}$ & $\begin{array}{c}423.3 \pm \\
90.45\end{array}$ & $2.43 \mathrm{E}-04$ & n.d \\
\hline DNA & $\mathrm{T}$ & ATP & $\begin{array}{l}0.1163 \pm \\
0.009014\end{array}$ & $\begin{array}{c}757.6 \pm \\
160\end{array}$ & $1.53 \mathrm{E}-04$ & \\
\hline DNA & G & СТP & $\begin{array}{l}0.1733 \pm \\
0.007439\end{array}$ & $\begin{array}{c}503.1 \pm \\
68.83\end{array}$ & $3.44 \mathrm{E}-04$ & \\
\hline DNA & $\mathrm{C}$ & GTP & $\begin{array}{c}0.01851 \pm \\
0.000891\end{array}$ & $\begin{array}{c}491.2 \pm \\
76.14\end{array}$ & $0.37 \mathrm{E}-04$ & \\
\hline DNA & A & UTP & - & - & - & \\
\hline
\end{tabular}

${ }^{a}$ Relative efficiency is calculated as the $\mathrm{Kcat} / \mathrm{Km}$ nucleotide insertion into RNA primer vs $\mathrm{Kcat} / \mathrm{Km}$ of nucleotide insertion into DNA primer.

Table 3: Parameters of RNA and DNA primer extensions with rNTPs by steady-state kinetics. 


\subsection{Discussion}

In this study, we discovered a novel function for the translesion DNA polymerase, Pol $\eta$. The results we obtained by analysing the sensitivity of $\mathrm{rad} 30 \Delta$ deletion strain on transcription elongation inhibitor, MPA containing media gave us an initial indication that Pol $\eta$ has some role to play in the mechanism of transcription and prompted us to investigate this further. So, we created double deletion strains, where alongside a rad30 $\Delta$ deletion, a known transcription factor was deleted. By examining the sensitivities of $\operatorname{rad} 30 \Delta d s t 1 \Delta$ and $\operatorname{rad} 30 \Delta \operatorname{snf} 5 \Delta$ we were able to conclude that Pol $\eta$ functions in same pathway as Dst1 but not Snf5. Dst1 is known to function as a transcription elongation factor, and Snf5 has a known role in chromatin remodelling. This led us to believe that Pol $\eta$ could have a role in transcription elongation. This clue was important in the design of further experiments to investigate the role of Pol $\eta$ in the process of transcription. Subsequently we performed experiments through which we could examine the transcription of galactose inducible genes, GAL1 and GAL10 by real time quantitative RT-PCR in rad30 $\Delta$ deletion strain. Indeed, deletion of $R A D 30$ decreased the levels of these galactose inducible genes which indicated clearly that Pol $\eta$ has a function in the transcription of these genes.

We obtained additional evidence for this by performing dual luciferase assay experiments where Pol $\eta$ was defective in the transcription of galactose inducible reporter gene, firefly luciferase and constitutively expressed reporter gene, renilla luciferase. This provided strong evidence that Pol $\eta$ affects the transcription of these genes and hence could have a role in the elongation function of transcription. We then performed in vivo assay for direct analysis of transcription elongation using the GLRO assay. We used an spt4 $\Delta$ deletion strain, which is known to have a defect in transcription elongation and also proved to be so by GLRO assay, as a positive control to validate the method and the results obtained clearly established that a rad30 deletion strain was defective in this in vivo transcription elongation assay. 
We further investigated if $\mathrm{Pol} \eta$ has a mere structural role or if the active centre of the protein which is known to have DNA synthesis activity needed for its transcriptional function. We made a genomic integration of the active centre mutant and used the strain to perform UV \& 6-AU sensitivity, and qPCR experiments. The results clearly showed that, the active centre mutant is similar to rad30 3 and is defective in the transcriptional role of Pol $\eta$.

According to the already known function of Pol $\eta$, it acts in error-free translesion synthesis of certain DNA lesions during replication. Though we noticed that deletion of $R A D 30$ caused a transcription elongation defect, it did not explain why its presence at the transcription elongation complex is needed., We hypothesized that Pol $\eta$ could help RNAPII to overcome obstacles by incorporating ribonucleotides into the nascent RNA. Particularly, Pol $\eta$ could possibly help in rapid bypass of DNA lesions so that transcription elongation could proceed.

To test this hypothesis, we performed in vitro primer extension assays and checked whether Pol $\eta$ can insert ribonucleotides to a growing RNA chain opposite to a DNA template. The results showed that Pol $\eta$ was indeed capable of ribonucleotide synthesis and we could establish that Pol $\eta$ inserts ribonucleotides into RNA much more efficiently than into DNA. Steady state kinetic analyses also strengthened the in vivo significance of this ribonucleotide incorporation activity. Kinetic analyses result also rule out the possibility that the ribonucleotide incorporation is because of the open conformation of the active site of translesion DNA polymerases which can accommodate a variety of substrates in their active site. We also tested the active centre mutant Pol $\eta$ D30A for ribonucleotide incorporation and found out that it was not capable of inserting ribonucleotides which confirmed that the active centre of the polymerase which is involved in DNA synthesis is also involved in RNA synthesis. We also performed in vitro primer extension assays with Pol $\eta$ using a template containing a most commonly occurring DNA damage such as 8-oxoguanine. Not only did 
we notice that Pol $\eta$ is capable of incorporating ribonucleotides opposite to 8-oxoG, but we also noticed that it does this in an error-free manner.

Our results led us to propose a model (Figure 20) for the transcription elongation role of Pol $\eta$. When RNA polymerase encounters DNA damage during transcription elongation, Pol $\eta$ can help bypass the damage by inserting ribonucleotides opposite the damage into the elongating RNA chain and help bypass the damage. This would allow for the cells to quickly overcome the damage and continue transcription.

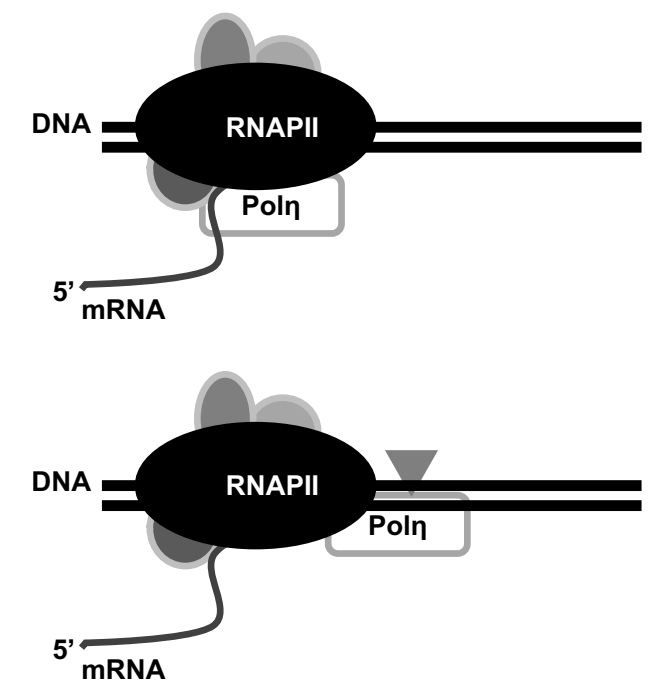
Pol $\eta$ acts as a transcription
elongation factor

When DNA lesions which stall RNA polymerase II are encountered Pol $\eta$ bypasses the lesion

Figure 20. Graphical summary of transcription elongation and ribonucleotide incorporation activities of Polymerase $\eta$. Grey colored circles behind RNAPII are its associated transcription elongation factors. Grey colored inverted triangle in the bottom panel of the figure indicates DNA damage.

When RNAPII encounters DNA lesions, it triggers TC-NER (Bowman et al, 1997a) which helps remove bulky lesions from the transcribed strand. However, recruitment of repair factors might not be enough for TC-NER to occur as the lesion might be buried within the stalled RNAPII and is not accessible to proteins that conduct TC-NER (Brueckner \& Cramer, 2008a). It has been shown that RNAPII may be removed from the site of DNA lesion by proteolytic degradation or by backward movement of the transcription elongation complex. 
It has been reported that RNAPII can perform lesion bypass when it encounters various types of lesions such as abasic sites or even single-strand breaks. However, this does not happen withouth transcriptional mutagenesis (Saxowsky \& Doetsch, 2006). Prolonged stalling of the RNAPII for TC-NER to occur or transcriptional mutagenesis is undesirable for genome stability.

A recent study proposed a model that RNAPII can switch between translesion and transcription modes (Walmacq et al, 2012). The translesion mode allows for low efficiency, low fidelity incorporation of NTPs to bypass lesions encountered during transcription and that regulatory factors that might regulate the lesion by pass are needed for this. These regulatory factors are yet unidentified. The results we obtained in this study point to a direction where Pol $\eta$ because of its ability to function as a transcription elongation factor and incorporate ribonucleotides can aid in the rapid bypass of lesions encountered during transcription and hence can contribute to the fidelity of nascent transcripts being transcribed. Further studies into this function of Pol $\eta$ would help shed more light on the exact mechanistic process of how Pol $\eta$ acts as a transcription elongation factor and also could have important implications on how fidelity is maintained during the transcription elongation. Mutational inactivation of human Pol $\eta$ causes a cancer-prone genetic disorder xeroderma pigmentosum variant (XP-V), characterized by an increased incidence of skin-cancer and sensitivity to sunlight. Studies on human Pol $\eta$ can uncover whether this disorder is partly because of its transcriptional function. 


\subsection{References}

Abrams E, Neigeborn L, Carlson M (1986) Molecular analysis of SNF2 and SNF5, genes required for expression of glucose-repressible genes in Saccharomyces cerevisiae. Molecular and cellular biology 6: 3643-3651

Archambault J, Lacroute F, Ruet A, Friesen JD (1992) Genetic interaction between transcription elongation factor TFIIS and RNA polymerase II. Molecular and cellular biology 12: $4142-4152$

Avkin S, Goldsmith M, Velasco-Miguel S, Geacintov N, Friedberg EC, Livneh Z (2004) Quantitative analysis of translesion DNA synthesis across a benzo[a]pyrene-guanine adduct in mammalian cells: the role of DNA polymerase kappa. The Journal of biological chemistry 279: 53298-53305

Belotserkovskaya R, Saunders A, Lis JT, Reinberg D (2004) Transcription through chromatin: understanding a complex FACT. Biochimica et biophysica acta 1677: 87-99

Bienko M, Green CM, Crosetto N, Rudolf F, Zapart G, Coull B, Kannouche P, Wider G, Peter M, Lehmann AR, Hofmann K, Dikic I (2005) Ubiquitin-binding domains in Y-family polymerases regulate translesion synthesis. Science 310: 1821-1824

Bienko M, Green CM, Sabbioneda S, Crosetto N, Matic I, Hibbert RG, Begovic T, Niimi A, Mann M, Lehmann AR, Dikic I (2010) Regulation of translesion synthesis DNA polymerase eta by monoubiquitination. Mol Cell 37: 396-407

Bowman KK, Smith CA, Hanawalt PC (1997a). Excision-repair patch lengths are similar for transcription-coupled repair and global genome repair in UV-irradiated human cells. Mutat Res

Mutation research; 1997.

Bowman KK, Smith CA, Hanawalt PC (1997b) Excision-repair patch lengths are similar for transcription-coupled repair and global genome repair in UV-irradiated human cells. Mutation research 385: 95-105

Bregman DB, Halaban R, van Gool AJ, Henning KA, Friedberg EC, Warren SL (1996) UVinduced ubiquitination of RNA polymerase II: a novel modification deficient in Cockayne syndrome cells. Proceedings of the National Academy of Sciences of the United States of America 93: 11586-11590

Brueckner F, Cramer P (2008a). Structural basis of transcription inhibition by alpha-amanitin and implications for RNA polymerase II translocation. Nat Struct Mol Biol

Nature structural \& molecular biology; 2008. 
Brueckner F, Cramer P (2008b) Structural basis of transcription inhibition by alpha-amanitin and implications for RNA polymerase II translocation. Nature structural \& molecular biology 15: $811-818$

Burgers PM (1991) Saccharomyces cerevisiae replication factor C. II. Formation and activity of complexes with the proliferating cell nuclear antigen and with DNA polymerases delta and epsilon. The Journal of biological chemistry 266: 22698-22706

Burgers PM (2009) Polymerase dynamics at the eukaryotic DNA replication fork. The Journal of biological chemistry 284: 4041-4045

Cairns BR, Kim YJ, Sayre MH, Laurent BC, Kornberg RD (1994) A multisubunit complex containing the SWI1/ADR6, SWI2/SNF2, SWI3, SNF5, and SNF6 gene products isolated from yeast. Proceedings of the National Academy of Sciences of the United States of America 91: 1950-1954

Caldecott KW (2008) Single-strand break repair and genetic disease. Nature reviews Genetics 9: 619-631

Conaway JW, Shilatifard A, Dvir A, Conaway RC (2000) Control of elongation by RNA polymerase II. Trends in biochemical sciences 25: 375-380

Costa PJ, Arndt KM (2000) Synthetic lethal interactions suggest a role for the Saccharomyces cerevisiae Rtf1 protein in transcription elongation. Genetics 156: 535-547

Daraba A, Gali VK, Halmai M, Haracska L, Unk I (2014) Def1 promotes the degradation of Pol3 for polymerase exchange to occur during DNA-damage--induced mutagenesis in Saccharomyces cerevisiae. PLoS Biol 12: e1001771

Davey MJ, O'Donnell M (2000) Mechanisms of DNA replication. Current opinion in chemical biology 4: 581-586

Davie JK, Kane CM (2000) Genetic interactions between TFIIS and the Swi-Snf chromatinremodeling complex. Molecular and cellular biology 20: 5960-5973

Exinger F, Lacroute F (1992) 6-Azauracil inhibition of GTP biosynthesis in Saccharomyces cerevisiae. Current genetics 22: 9-11

Fish RN, Kane CM (2002) Promoting elongation with transcript cleavage stimulatory factors. Biochimica et biophysica acta 1577: 287-307 
Friedberg EC (2005) Suffering in silence: the tolerance of DNA damage. Nature reviews Molecular cell biology 6: 943-953

Gietz RD, Schiestl RH (2007) High-efficiency yeast transformation using the LiAc/SS carrier DNA/PEG method. Nature protocols 2: 31-34

Gnatt A (2002) Elongation by RNA polymerase II: structure-function relationship. Biochimica et biophysica acta 1577: 175-190

Gray M, Kupiec M, Honigberg SM (2004) Site-specific genomic (SSG) and random domainlocalized (RDL) mutagenesis in yeast. BMC Biotechnol 4: 7

Gu W, Powell W, Mote J, Jr., Reines D (1993) Nascent RNA cleavage by arrested RNA polymerase II does not require upstream translocation of the elongation complex on DNA. The Journal of biological chemistry 268: 25604-25616

Hahn S (2004) Structure and mechanism of the RNA polymerase II transcription machinery. Nature structural \& molecular biology 11: 394-403

Happel AM, Swanson MS, Winston F (1991) The SNF2, SNF5 and SNF6 genes are required for Ty transcription in Saccharomyces cerevisiae. Genetics 128: 69-77

Haracska L, Johnson RE, Unk I, Phillips B, Hurwitz J, Prakash L, Prakash S (2001a) Physical and functional interactions of human DNA polymerase eta with PCNA. Molecular and cellular biology 21: 7199-7206

Haracska L, Prakash L, Prakash S (2002) Role of human DNA polymerase kappa as an extender in translesion synthesis. Proceedings of the National Academy of Sciences of the United States of America 99: 16000-16005

Haracska L, Prakash S, Prakash L (2000a) Replication past O(6)-methylguanine by yeast and human DNA polymerase eta. Molecular and cellular biology 20: 8001-8007

Haracska L, Prakash S, Prakash L (2003) Yeast DNA polymerase zeta is an efficient extender of primer ends opposite from 7,8-dihydro-8-Oxoguanine and O6-methylguanine. Molecular and cellular biology 23: 1453-1459

Haracska L, Unk I, Johnson RE, Johansson E, Burgers PM, Prakash S, Prakash L (2001b) Roles of yeast DNA polymerases delta and zeta and of Rev1 in the bypass of abasic sites. Genes \& development 15: 945-954 
Haracska L, Yu SL, Johnson RE, Prakash L, Prakash S (2000b) Efficient and accurate replication in the presence of 7,8-dihydro-8-oxoguanine by DNA polymerase eta. Nature genetics 25: 458-461

Hartzog GA, Wada T, Handa H, Winston F (1998) Evidence that Spt4, Spt5, and Spt6 control transcription elongation by RNA polymerase II in Saccharomyces cerevisiae. Genes \& development 12: 357-369

Hemming SA, Jansma DB, Macgregor PF, Goryachev A, Friesen JD, Edwards AM (2000) RNA polymerase II subunit Rpb9 regulates transcription elongation in vivo. The Journal of biological chemistry 275: 35506-35511

Hirschhorn JN, Brown SA, Clark CD, Winston F (1992) Evidence that SNF2/SWI2 and SNF5 activate transcription in yeast by altering chromatin structure. Genes \& development 6: 22882298

Hoeijmakers JH (2009) DNA damage, aging, and cancer. The New England journal of medicine 361: 1475-1485

Ishiguro A, Nogi Y, Hisatake K, Muramatsu M, Ishihama A (2000) The Rpb6 subunit of fission yeast RNA polymerase II is a contact target of the transcription elongation factor TFIIS. Molecular and cellular biology 20: 1263-1270

Izban MG, Luse DS (1993) The increment of SII-facilitated transcript cleavage varies dramatically between elongation competent and incompetent RNA polymerase II ternary complexes. The Journal of biological chemistry 268: 12874-12885

Jiricny J (2006) The multifaceted mismatch-repair system. Nature reviews Molecular cell biology 7: 335-346

Johnson RE, Prakash L, Prakash S (2006) Yeast and human translesion DNA synthesis polymerases: expression, purification, and biochemical characterization. Methods Enzymol 408: $390-407$

Johnson RE, Washington MT, Prakash S, Prakash L (2000) Fidelity of human DNA polymerase eta. The Journal of biological chemistry 275: 7447-7450

Johnson SJ, Beese LS (2004) Structures of mismatch replication errors observed in a DNA polymerase. Cell 116: $803-816$

Jung YS, Liu G, Chen X (2010) Pirh2 E3 ubiquitin ligase targets DNA polymerase eta for 20S proteasomal degradation. Molecular and cellular biology 30: 1041-1048 
Kannouche P, Broughton BC, Volker M, Hanaoka F, Mullenders LH, Lehmann AR (2001) Domain structure, localization, and function of DNA polymerase eta, defective in xeroderma pigmentosum variant cells. Genes \& development 15: 158-172

Kannouche PL, Wing J, Lehmann AR (2004) Interaction of human DNA polymerase eta with monoubiquitinated PCNA: a possible mechanism for the polymerase switch in response to DNA damage. Mol Cell 14: 491-500

Kaplan CD, Larsson KM, Kornberg RD (2008) The RNA polymerase II trigger loop functions in substrate selection and is directly targeted by alpha-amanitin. Mol Cell 30: 547-556

Kawamoto T, Araki K, Sonoda E, Yamashita YM, Harada K, Kikuchi K, Masutani C, Hanaoka F, Nozaki K, Hashimoto N, Takeda S (2005a). Dual roles for DNA polymerase eta in homologous DNA recombination and translesion DNA synthesis. Mol Cell

Molecular cell; 2005.

Kawamoto T, Araki K, Sonoda E, Yamashita YM, Harada K, Kikuchi K, Masutani C, Hanaoka F, Nozaki K, Hashimoto N, Takeda S (2005b) Dual roles for DNA polymerase eta in homologous DNA recombination and translesion DNA synthesis. Mol Cell 20: 793-799

Kettenberger H, Armache KJ, Cramer P (2003) Architecture of the RNA polymerase II-TFIIS complex and implications for mRNA cleavage. Cell 114: 347-357

Kireeva ML, Komissarova N, Waugh DS, Kashlev M (2000) The 8-nucleotide-long RNA:DNA hybrid is a primary stability determinant of the RNA polymerase II elongation complex. The Journal of biological chemistry 275: 6530-6536

Komissarova N, Kashlev M (1997) Transcriptional arrest: Escherichia coli RNA polymerase translocates backward, leaving the 3' end of the RNA intact and extruded. Proceedings of the National Academy of Sciences of the United States of America 94: 1755-1760

Kondratick CM, Washington MT, Prakash S, Prakash L (2001) Acidic residues critical for the activity and biological function of yeast DNA polymerase eta. Molecular and cellular biology 21: 2018-2025

Kornberg RD (2007) The molecular basis of eukaryotic transcription. Proceedings of the National Academy of Sciences of the United States of America 104: 12955-12961

Krogan NJ, Kim M, Ahn SH, Zhong G, Kobor MS, Cagney G, Emili A, Shilatifard A, Buratowski S, Greenblatt JF (2002) RNA polymerase II elongation factors of Saccharomyces cerevisiae: a targeted proteomics approach. Molecular and cellular biology 22: 6979-6992 
Kunkel TA, Burgers PM (2008) Dividing the workload at a eukaryotic replication fork. Trends in cell biology 18: 521-527

Kuras L, Struhl K (1999) Binding of TBP to promoters in vivo is stimulated by activators and requires Pol II holoenzyme. Nature 399: 609-613

Labhart P, Morgan GT (1998) Identification of novel genes encoding transcription elongation factor TFIIS (TCEA) in vertebrates: conservation of three distinct TFIIS isoforms in frog, mouse, and human. Genomics 52: 278-288

Laurent BC, Treitel MA, Carlson M (1990) The SNF5 protein of Saccharomyces cerevisiae is a glutamine- and proline-rich transcriptional activator that affects expression of a broad spectrum of genes. Molecular and cellular biology 10: 5616-5625

Laurent BC, Treitel MA, Carlson M (1991) Functional interdependence of the yeast SNF2, SNF5, and SNF6 proteins in transcriptional activation. Proceedings of the National Academy of Sciences of the United States of America 88: 2687-2691

Lehmann AR (2005) Replication of damaged DNA by translesion synthesis in human cells. FEBS letters 579: 873-876

Lennon JC, 3rd, Wind M, Saunders L, Hock MB, Reines D (1998) Mutations in RNA polymerase II and elongation factor SII severely reduce mRNA levels in Saccharomyces cerevisiae. Molecular and cellular biology 18: 5771-5779

Lichon V, Khachemoune A (2007) Xeroderma pigmentosum: beyond skin cancer. Journal of drugs in dermatology: JDD 6: 281-288

Lindahl T (1993) Instability and decay of the primary structure of DNA. Nature 362: 709-715

Lindahl T, Barnes DE (2000) Repair of endogenous DNA damage. Cold Spring Harbor symposia on quantitative biology 65: 127-133

Malone EA, Clark CD, Chiang A, Winston F (1991) Mutations in SPT16/CDC68 suppress cisand trans-acting mutations that affect promoter function in Saccharomyces cerevisiae. Molecular and cellular biology 11: 5710-5717

Marietta C, Brooks PJ (2007) Transcriptional bypass of bulky DNA lesions causes new mutant RNA transcripts in human cells. EMBO reports 8: 388-393 
Masutani C, Kusumoto R, Yamada A, Dohmae N, Yokoi M, Yuasa M, Araki M, Iwai S, Takio K, Hanaoka F (1999) The XPV (xeroderma pigmentosum variant) gene encodes human DNA polymerase eta. Nature 399: 700-704

McCulloch SD, Kunkel TA (2008) The fidelity of DNA synthesis by eukaryotic replicative and translesion synthesis polymerases. Cell research 18: 148-161

McDonald JP, Levine AS, Woodgate R (1997) The Saccharomyces cerevisiae RAD30 gene, a homologue of Escherichia coli dinB and umuC, is DNA damage inducible and functions in a novel error-free postreplication repair mechanism. Genetics 147: 1557-1568

McGlynn P, Lloyd RG (2002) Recombinational repair and restart of damaged replication forks. Nature reviews Molecular cell biology 3: 859-870

McNabb DS, Reed R, Marciniak RA (2005) Dual luciferase assay system for rapid assessment of gene expression in Saccharomyces cerevisiae. Eukaryotic cell 4: 1539-1549

Mellon I, Spivak G, Hanawalt PC (1987) Selective removal of transcription-blocking DNA damage from the transcribed strand of the mammalian DHFR gene. Cell 51: 241-249

Moldovan GL, D'Andrea AD (2009) How the fanconi anemia pathway guards the genome. Annual review of genetics 43: 223-249

Mueller CL, Jaehning JA (2002) Ctr9, Rtf1, and Leo1 are components of the Paf1/RNA polymerase II complex. Molecular and cellular biology 22: 1971-1980

Nair DT, Johnson RE, Prakash L, Prakash S, Aggarwal AK (2005) Rev1 employs a novel mechanism of DNA synthesis using a protein template. Science 309: 2219-2222

Nakanishi T, Nakano A, Nomura K, Sekimizu K, Natori S (1992) Purification, gene cloning, and gene disruption of the transcription elongation factor S-II in Saccharomyces cerevisiae. The Journal of biological chemistry 267: 13200-13204

Nick McElhinny SA, Gordenin DA, Stith CM, Burgers PM, Kunkel TA (2008) Division of labor at the eukaryotic replication fork. Mol Cell 30: 137-144

Nick McElhinny SA, Watts BE, Kumar D, Watt DL, Lundstrom EB, Burgers PM, Johansson E, Chabes A, Kunkel TA (2010) Abundant ribonucleotide incorporation into DNA by yeast replicative polymerases. Proc Natl Acad Sci U S A 107: 4949-4954 
Nikolaishvili-Feinberg N, Jenkins GS, Nevis KR, Staus DP, Scarlett CO, Unsal-Kacmaz K, Kaufmann WK, Cordeiro-Stone M (2008) Ubiquitylation of proliferating cell nuclear antigen and recruitment of human DNA polymerase eta. Biochemistry 47: 4141-4150

Ogi T, Shinkai Y, Tanaka K, Ohmori H (2002) Polkappa protects mammalian cells against the lethal and mutagenic effects of benzo[a]pyrene. Proceedings of the National Academy of Sciences of the United States of America 99: 15548-15553

Ohmori H, Friedberg EC, Fuchs RP, Goodman MF, Hanaoka F, Hinkle D, Kunkel TA, Lawrence CW, Livneh Z, Nohmi T, Prakash L, Prakash S, Todo T, Walker GC, Wang Z, Woodgate R (2001) The Y-family of DNA polymerases. Mol Cell 8: 7-8

Orphanides G, LeRoy G, Chang CH, Luse DS, Reinberg D (1998) FACT, a factor that facilitates transcript elongation through nucleosomes. Cell 92: 105-116

Orphanides G, Wu WH, Lane WS, Hampsey M, Reinberg D (1999) The chromatin-specific transcription elongation factor FACT comprises human SPT16 and SSRP1 proteins. Nature 400: $284-288$

Peterson CL, Dingwall A, Scott MP (1994) Five SWI/SNF gene products are components of a large multisubunit complex required for transcriptional enhancement. Proceedings of the National Academy of Sciences of the United States of America 91: 2905-2908

Plosky BS, Vidal AE, Fernandez de Henestrosa AR, McLenigan MP, McDonald JP, Mead S, Woodgate R (2006) Controlling the subcellular localization of DNA polymerases iota and eta via interactions with ubiquitin. The EMBO journal 25: 2847-2855

Pokholok DK, Hannett NM, Young RA (2002a) Exchange of RNA polymerase II initiation and elongation factors during gene expression in vivo. Mol Cell 9: 799-809

Pokholok DK, Hannett NM, Young RA (2002b) Exchange of RNA polymerase II initiation and elongation factors during gene expression in vivo. Mol Cell 9: 799-809

Powell W, Reines D (1996) Mutations in the second largest subunit of RNA polymerase II cause 6-azauracil sensitivity in yeast and increased transcriptional arrest in vitro. The Journal of biological chemistry 271: 6866-6873

Prakash S, Johnson RE, Prakash L (2005) Eukaryotic translesion synthesis DNA polymerases: specificity of structure and function. Annual review of biochemistry 74: 317-353

Ratner JN, Balasubramanian B, Corden J, Warren SL, Bregman DB (1998) Ultraviolet radiation-induced ubiquitination and proteasomal degradation of the large subunit of RNA 
polymerase II. Implications for transcription-coupled DNA repair. The Journal of biological chemistry 273: 5184-5189

Reines D, Conaway RC, Conaway JW (1999) Mechanism and regulation of transcriptional elongation by RNA polymerase II. Current opinion in cell biology 11: 342-346

Rowley A, Singer RA, Johnston GC (1991) CDC68, a yeast gene that affects regulation of cell proliferation and transcription, encodes a protein with a highly acidic carboxyl terminus. Molecular and cellular biology 11: 5718-5726

Rudd MD, Izban MG, Luse DS (1994) The active site of RNA polymerase II participates in transcript cleavage within arrested ternary complexes. Proceedings of the National Academy of Sciences of the United States of America 91: 8057-8061

Sarker AH, Tsutakawa SE, Kostek S, Ng C, Shin DS, Peris M, Campeau E, Tainer JA, Nogales E, Cooper PK (2005) Recognition of RNA polymerase II and transcription bubbles by XPG, CSB, and TFIIH: insights for transcription-coupled repair and Cockayne Syndrome. Mol Cell 20: $187-198$

Saxowsky TT, Doetsch PW (2006) RNA polymerase encounters with DNA damage: transcription-coupled repair or transcriptional mutagenesis? Chemical reviews 106: 474-488

Selby CP, Sancar A (1997) Human transcription-repair coupling factor CSB/ERCC6 is a DNAstimulated ATPase but is not a helicase and does not disrupt the ternary transcription complex of stalled RNA polymerase II. The Journal of biological chemistry 272: 1885-1890

Shaw RJ, Reines D (2000) Saccharomyces cerevisiae transcription elongation mutants are defective in PUR5 induction in response to nucleotide depletion. Mol Cell Biol 20: 7427-7437

Shi X, Chang M, Wolf AJ, Chang CH, Frazer-Abel AA, Wade PA, Burton ZF, Jaehning JA (1997) Cdc73p and Paflp are found in a novel RNA polymerase II-containing complex distinct from the Srbp-containing holoenzyme. Molecular and cellular biology 17: 1160-1169

Shi X, Finkelstein A, Wolf AJ, Wade PA, Burton ZF, Jaehning JA (1996) Paflp, an RNA polymerase II-associated factor in Saccharomyces cerevisiae, may have both positive and negative roles in transcription. Molecular and cellular biology 16: 669-676

Sims RJ, 3rd, Belotserkovskaya R, Reinberg D (2004) Elongation by RNA polymerase II: the short and long of it. Genes \& development 18: 2437-2468 
Smith CL, Horowitz-Scherer R, Flanagan JF, Woodcock CL, Peterson CL (2003) Structural analysis of the yeast SWI/SNF chromatin remodeling complex. Nature structural biology 10: $141-145$

Steinmetz EJ, Brow DA (2003) Ssu72 protein mediates both poly(A)-coupled and poly(A)independent termination of RNA polymerase II transcription. Mol Cell Biol 23: 6339-6349

Svejstrup JQ (2002) Mechanisms of transcription-coupled DNA repair. Nature reviews Molecular cell biology 3: 21-29

Swan MK, Johnson RE, Prakash L, Prakash S, Aggarwal AK (2009) Structural basis of highfidelity DNA synthesis by yeast DNA polymerase delta. Nature structural \& molecular biology 16: $979-986$

Takenaka K, Ogi T, Okada T, Sonoda E, Guo C, Friedberg EC, Takeda S (2006) Involvement of vertebrate Polkappa in translesion DNA synthesis across DNA monoalkylation damage. The Journal of biological chemistry 281: 2000-2004

Teste MA, Duquenne M, Francois JM, Parrou JL (2009) Validation of reference genes for quantitative expression analysis by real-time RT-PCR in Saccharomyces cerevisiae. BMC Mol Biol 10: 99

Tornaletti S, Donahue BA, Reines D, Hanawalt PC (1997) Nucleotide sequence context effect of a cyclobutane pyrimidine dimer upon RNA polymerase II transcription. The Journal of biological chemistry 272: 31719-31724

Tornaletti S, Reines D, Hanawalt PC (1999) Structural characterization of RNA polymerase II complexes arrested by a cyclobutane pyrimidine dimer in the transcribed strand of template DNA. The Journal of biological chemistry 274: 24124-24130

Tous C, Rondon AG, Garcia-Rubio M, Gonzalez-Aguilera C, Luna R, Aguilera A (2011) A novel assay identifies transcript elongation roles for the Nup84 complex and RNA processing factors. The EMBO journal 30: 1953-1964

Trincao J, Johnson RE, Escalante CR, Prakash S, Prakash L, Aggarwal AK (2001) Structure of the catalytic core of S. cerevisiae DNA polymerase eta: implications for translesion DNA synthesis. Mol Cell 8: 417-426

Wade JT, Struhl K (2008) The transition from transcriptional initiation to elongation. Current opinion in genetics \& development 18: 130-136 
Walmacq C, Cheung AC, Kireeva ML, Lubkowska L, Ye C, Gotte D, Strathern JN, Carell T, Cramer P, Kashlev M (2012) Mechanism of translesion transcription by RNA polymerase II and its role in cellular resistance to DNA damage. Mol Cell 46: 18-29

Wang D, Bushnell DA, Westover KD, Kaplan CD, Kornberg RD (2006) Structural basis of transcription: role of the trigger loop in substrate specificity and catalysis. Cell 127: 941-954

Washington MT, Johnson RE, Prakash S, Prakash L (2000) Accuracy of thymine-thymine dimer bypass by Saccharomyces cerevisiae DNA polymerase eta. Proceedings of the National Academy of Sciences of the United States of America 97: 3094-3099

Washington MT, Minko IG, Johnson RE, Wolfle WT, Harris TM, Lloyd RS, Prakash S, Prakash L (2004) Efficient and error-free replication past a minor-groove DNA adduct by the sequential action of human DNA polymerases iota and kappa. Molecular and cellular biology 24: $5687-5693$

Waters LS, Minesinger BK, Wiltrout ME, D'Souza S, Woodruff RV, Walker GC (2009) Eukaryotic translesion polymerases and their roles and regulation in DNA damage tolerance. Microbiology and molecular biology reviews : MMBR 73: 134-154

Wind M, Reines D (2000) Transcription elongation factor SII. BioEssays : news and reviews in molecular, cellular and developmental biology 22: 327-336

Winston F, Sudarsanam P (1998) The SAGA of Spt proteins and transcriptional analysis in yeast: past, present, and future. Cold Spring Harbor symposia on quantitative biology 63: 553561

Woudstra EC, Gilbert C, Fellows J, Jansen L, Brouwer J, Erdjument-Bromage H, Tempst P, Svejstrup JQ (2002a). A Rad26-Def1 complex coordinates repair and RNA pol II proteolysis in response to DNA damage. Nature; 2002.

Woudstra EC, Gilbert C, Fellows J, Jansen L, Brouwer J, Erdjument-Bromage H, Tempst P, Svejstrup JQ (2002b) A Rad26-Def1 complex coordinates repair and RNA pol II proteolysis in response to DNA damage. Nature 415: 929-933

Wu J, Awrey DE, Edwards AM, Archambault J, Friesen JD (1996) In vitro characterization of mutant yeast RNA polymerase II with reduced binding for elongation factor TFIIS. Proceedings of the National Academy of Sciences of the United States of America 93: 1155211557 


\subsection{Acknowledgement}

It is my great pleasure to sincerely acknowledge everyone who has encouraged, supported and guided me in my endeavour to take up a research career.

Foremost, my deep sense of gratitude to my supervisor, Dr. Unk Ildiko who has given me the opportunity to be a part of her research group and for her valuable guidance and encouragement throughout my $\mathrm{PhD}$.

This work was supported by the OTKA 109521 grant, and grants from the National Research, Development and Innovation Office: GINOP-2.3.2-15-2016-00001 and GINOP-2.3.2-152016-00024.

I would also like to greatly thank Dr. Balint Eva who has made an invaluable contribution to some experiments in this thesis. It has been a pleasure working with her as a colleague and taking part in scientific discussions.

Thanks to all other members of the DNA repair group for their kind support and co-operation, much needed for me to able to work in the lab, especially to Minorits Szilvi for her technical assistance. I would also like to thank Dr. Haracska Lajos and his lab members for their friendly association with our research group.

I also take this opportunity to express my gratitude to all the administrative staff at the Institute of Genetics, and the Biological Research Centre.

This section would be incomplete if I don't mention about my friends, the ITC community and everyone else who contributed to all the memorable experiences I had outside the lab in Szeged.

I appreciate the kind support of all my family members during my $\mathrm{PhD}$. 


\subsection{Summary}

DNA lesions are obstacles not only to the process of replication but also transcription. Arrested transcription complexes may severely affect several cellular functions and survival, inhibiting the production of essential transcripts, blocking DNA replication, and signalling cell death pathways. Moreover, an RNA polymerase able to bypass a lesion can generate mutant, perhaps deleterious, transcripts. There are a variety of hypotheses that have been proposed for the blocked polymerase to deal with transcription-blocking lesions which include backtracking of the RNA polymerase II, its ubiquitination and proteasome mediated degradation, transcription coupled nucleotide excision repair or lesion bypass mediated by accessory factors. During my $\mathrm{PhD}$ work, we have identified a novel and hitherto unknown function for a translesion DNA polymerase of yeast, polymerase $\eta$ (eta). Pol $\eta$ is a well-studied translesion DNA polymerase which is known for its role in error-free bypass of DNA damage, functioning in the post replication repair pathway mediated by Rad6-Rad18. Here, we show that Pol $\eta$ functions in transcription elongation and it is capable to bypass DNA lesions by incorporating ribonucleotides.

First, we identified that lack of Pol $\eta$ by deletion of $R A D 30$ in yeast cells makes them sensitive to transcription elongation inhibitors like mycophenolic acid. This prompted us to investigate further to check if Pol $\eta$ indeed played a role in transcription elongation. We performed dual luciferase assay, where expression of firefly and Renilla luciferase genes under the control of galactose inducible and constitutive promoters respectively were examined. The results showed that in the absence of Pol $\eta$, their expression is defective. We observed similar defect in $\mathrm{rad} 30$ strain when we examined induced synthesis of GAL1 and GAL10 genes by reverse transcription and real time (RT-qPCR). We also performed a direct in vivo assay for analysis of elongation on chromatin, GLRO assay, using the relatively long lacZ gene that has a high 
GC content and mutants impaired in the process of transcription elongation are defective in transcribing this gene. Here, we noticed that rad30 strain was defective in transcribing the lacZ gene. These experiments led us to conclude that the observed sensitivity of rad30 strains was as a result of direct involvement of Pol $\eta$ in transcription elongation.

The results obtained encouraged us to analyse whether the polymerase activity of Pol $\eta$ is needed for its transcription elongation role or if it has a mere structural role. We studied the effect of single point mutant inactivating the polymerase domain of Pol $\eta$ by integrating it at the genomic locus of $R A D 30$. Sensitivity to 6-aauracil, and RT-qPCR experiments, showed that the active centre which controls its catalytic activity is important for the transcriptional function of Pol $\eta$.

According to the already well-established function of Pol $\eta$, it acts in the error free bypass of DNA lesions during replication. So, we hypothesized that Pol $\eta$ might rescue the elongation complex by incorporating ribonucleotides into elongating mRNA, opposite to damaged DNA. To investigate this possibility, we performed in vitro primer extensions assays by using purified Pol $\eta$ and substrates containing DNA template with RNA primer and all four rNTPs and found that Pol $\eta$ could catalyse addition of ribonucleotides into RNA. Steady-state kinetic analyses for incorporation of single NTP studies have shown that Pol $\eta$ can insert ribonucleotides into RNA with a higher efficiency than into DNA. This proved that insertion of ribonucleotides is specific to RNA. We could also show that Pol $\eta$ can incorporate ribonucleotides opposite to a lesion in DNA template such as 8-oxoguanine in an error-free manner.

The above results helped us to discover a novel process in transcription where a DNA polymerase acts as a transcription elongation factor and deletion of this gene leads to reduced mRNA synthesis. In addition, it is also capable of inserting ribonucleotides into RNA and also opposite to a commonly occurring DNA lesion such as 8-oxoguanine, which shows an important significance to this discovery, the elongating transcription machinery has a rapid and 
efficient way of bypassing some types of lesions which could otherwise lead to stalled RNA pol II complexes and eventually cell death. Mutational inactivation of human Pol $\eta$ leads to a cancer-prone genetic disorder xeroderma pigmentosum variant (XP-V) and further studies in human cells on similar lines could lead to significant advances in understanding the disorder. 


\section{0 Összefoglalás}

A DNS károsodások akadályt jelentenek nem csak a replikáció folyamán, hanem a transzkripció számára is. Megállt transzkripciós komplexek súlyosan befolyásolhatják a sejt müködését és túlélését az által, hogy esszenciális transzkriptumok képződését gátolják, a DNS replikációt blokkolják, és sejthalál útvonalakat indítanak be. Ha az RNS polimeráz át tud haladni a DNS hibán, akkor mutáns, a sejt számára káros transzkriptumot képezhet. Számos hipotézis létezik arra, hogy a megakadt RNS polimeráz hogyan kezeli a transzkripciót blokkoló léziókat: az RNS polimeráz visszafelé mozoghat (backtracking), ubiquitinálódhat és proteaszóma által degradálódhat, lejátszódhat transzkripcióhoz kapcsolt nukleotid kimetszéses javítás (TC-NER), vagy a lézió átírása járulékos faktorok segítségével.

PhD munkám során egy élesztő transzléziós DNS polimeráz, a Pol éta (ๆ) új, eddig ismeretlen szerepét mutattam ki. A Pol $\eta$ már sokat tanulmányozott fehérje. Jól ismert a DNS károsodás hibamentes átírásában betöltött szerepe, a Rad6-Rad18 által irányított posztreplikációs javítási útvonalban vesz részt. Munkám során kimutattam, hogy a Pol $\eta$ közremüködik a transzkripció elongációban és képes a transzkripció megtorpanását okozó DNS hibákkal szemben ribonukleotidok beépítésére.

Elöször is kimutattuk, hogy a Pol ๆ (amelyet élesztőben Rad30 gén kódol) hiányos, deléciós élesztők érzékenyek a transzkripció elongáció inhibitoraira, például mikofenolsavra. Ezért megvizsgáltuk, hogy a Pol $\eta$ szerepet játszhat-e a transzkripció elongációban. Ehhez kettős luciferáz riporter assay-t alkalmaztunk, ahol a szentjánosbogár (Photinus sp., ismertebb angol nevén firefly) luciferáz gén expresszióját galaktóz indukálható promóter, míg a Renilla (Renilla reniformis, tengeri árvácska) luciferáz gén expresszióját konstitutív promóter irányítja. Megállapítottuk, hogy Pol $\eta$ hiányában az expresszió alacsonyabb volt mindkét promóterről. Megvizsgáltuk az endogén GAL1 és GAL10 gének indukált expresszióját vad típusú és rad30 deléciós törzsben reverz transzkripciót követő valós idejü kvantitatív polimeráz 
láncreakció (RT-qPCR) használatával. Azt tapasztaltuk, hogy Pol $\eta$ hiányában e gének indukciója is hibát szenved. A transzkripció elongáció tanulmányozására direkt in vivo kísérletet (G-mentesre futtatás, G-less based Run-on, GLRO) végeztünk a LacZ kódoló régió használatával, amely relatív hossza és magas GC tartalma miatt alkalmas az elongáció hatékonyságának vizsgálatára. Azt tapasztaltuk, hogy a rad30 deléciós törzs az ismert elongációs mutánsokhoz hasonlóan rosszabb hatásfokkal írodik át a lacZ gén. Mindezek alapján arra következtettünk, hogy a rad30 deléciós törzs mikofenolsav érzékenységét az okozza, hogy a Pol $\eta$ közvetlenül részt vesz a transzkripció elongációban.

A kapott eredmények annak elemzésére ösztönöztek bennünket, hogy vajon a transzkripció elongációban szükség van-e a Pol $\eta$ polimeráz aktivitására, vagy egyszerüen struktúrális szerepet tölt be. A polimeráz aktív centrumát inaktiváló egyetlen pontmutáció hatását vizsgáltuk úgy, hogy azt a $R A D 30$ genomi lókuszába integráltuk. Mind a mikofenolsav érzékenység, és az RT-qPCR azt mutatták, hogy a mutáns úgy viselkedett, mint a deléciós törzs, tehát a Pol ๆ polimeráz aktivitásnak szerepe van a transzkripció elongációban.

A Pol $\eta$ jól ismert funkciója a DNS károsodás hibamentes átírása. Feltételeztük, hogy hasonlóan, a transzkripció megtorpanását okozó DNS károsodás esetén Pol $\eta$ gyorsan menekítheti az elongációs komplexet, oly módon, hogy a károsodott nukleotiddal szemben ribonukleotidokat épít be a szintetizálódó RNS-be. E feltételezés megvizsgálására in vitro primer extenziós vizsgálatot végeztünk tisztított Pol $\eta$ valamint DNS-templátot, RNS primert és mind a négy rNTP-t tartalmazó szubsztrát felhasználásával. Pol $\eta$ képes volt RNS-hez ribonukleotidokat hozzáépíteni.. Az egyes NTP-k beépítésének steady-state kinetikai elemzése kimutatta, hogy a Pol $\eta$ magasabb hatásfokkal épít be ribonukleotidokat RNS-be, mint DNSbe. Ez azt mutatja, hogy ribonukleotidok beillesztése RNS specifikus. Azt is kimutattuk, hogy a Pol $\eta$ DNS lézióval, például a 8-oxoguaninnal szemben is tud ribonukleotidokat beépíteni. 
A fenti eredmények által a transzkripció egy új folyamatát fedeztük fel, amikor is egy DNS polimeráz transzkripciós elongációs faktorként funkcionál, és deléciója csökkent mRNS szintézishez vezet. Ezen kívül ez a polimeráz képes RNS-be ribonukleotidokat beépíteni, sőt egy gyakran előforduló károsodott nukleotidot, a 8-oxoguanint is képes templátjául használni. Ez által a transzkripció gyors és hatékony módon tud áthaladni bizonyos DNS károsodásokon, amelyek különben az RNS polimeráz II megakadását okoznák és sejthalálhoz vezethetnek. A humán Pol $\eta$ mutációk általi inaktivációja genetikai szindrómához, a Xeroderma pigmentózum variáns formájához $(\mathrm{XP}-\mathrm{V})$ vezetnek. E betegség megértéséhez közelebb vihet a humán pol $\eta$ transzkripcióban betöltött esetleges funkciójának vizsgálata. 